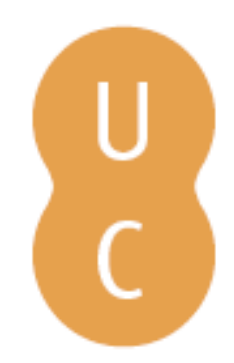

\title{
nombalina
}

\section{Modelos de ensino e aprendizagem da História: da formação enciclopédica à especialização (1901-1957)}

Autor(es): $\quad$ Mota, Luís; Ferreira, António Gomes

Publicado por: Imprensa da Universidade de Coimbra

URL

persistente: URI:http://hdl.handle.net/10316.2/38580

DOI: $\quad$ DOI:http://dx.doi.org/10.14195/978-989-26-0646-0_9

Accessed : $\quad$ 26-Apr-2023 13:14:13

A navegação consulta e descarregamento dos títulos inseridos nas Bibliotecas Digitais UC Digitalis, UC Pombalina e UC Impactum, pressupõem a aceitação plena e sem reservas dos Termos e Condições de Uso destas Bibliotecas Digitais, disponíveis em https://digitalis.uc.pt/pt-pt/termos.

Conforme exposto nos referidos Termos e Condições de Uso, o descarregamento de títulos de acesso restrito requer uma licença válida de autorização devendo o utilizador aceder ao(s) documento(s) a partir de um endereço de IP da instituição detentora da supramencionada licença.

Ao utilizador é apenas permitido o descarregamento para uso pessoal, pelo que o emprego do(s) título(s) descarregado(s) para outro fim, designadamente comercial, carece de autorização do respetivo autor ou editor da obra.

Na medida em que todas as obras da UC Digitalis se encontram protegidas pelo Código do Direito de Autor e Direitos Conexos e demais legislação aplicável, toda a cópia, parcial ou total, deste documento, nos casos em que é legalmente admitida, deverá conter ou fazer-se acompanhar por este aviso. 


\section{MODELOS DE ENSINO E APRENDIZAgEM DA Histónia. DA FORMAÇÃO ENCICLOPÉDICA À ESPECIALIZAÇÃO (1901-1957)}

LUÍs MOTA

ANTÓNIO GOMES FERREIRA

\section{Clarificação e problemática de um objeto de estudo}

O reconhecimento da proposta de trabalho que nos foi endereçada pela comissão organizadora do colóquio Historiografias portuguesa e brasileira no século $X X$, enquadrada no painel denominado Instituições e organizações de produção, reprodução e divulgação de discursos historiográficos, incorpora, desde logo, a consciência da sua complexidade em face dos condicionalismos presentes em qualquer produção historiográfica. Uma complexidade que envolve, só por si, as condicionantes exteriores aos historiadores e às historiadoras e aquelas que lhe são mais próximas, servindo para tanto as elencadas por Amado Mendes ${ }^{1}$, como sejam as de índole biográfica - a origem, a formação, as vivências e convivências, as atividades e as responsabilidades.

É certo que temos hoje disponíveis importantes contributos, dos quais nos autorizamos a salientar, entre outros os de Amado Mendes ${ }^{2}$, Sérgio Campos

${ }^{1}$ Cf. Mendes, J. Amado - Desenvolvimento e estruturação da historiografia portuguesa. In Torgal, Luís Reis; Mendes, José Maria Amado; Catroga, Fernando - História da História em Portugal. Séculos XIX e XX. Lisboa: Círculo de Leitores, 1996, p. 161. ISBN 972-42-1384-6.

2 Mendes, J. Amado - A História da Faculdade de Letras da Universidade de Coimbra: Investigação e Ensino (1911-1926). In Universidade(s). História. Memória. Perspetivas. Actas do 
Matos $^{3}$ ou a reflexão crítica de Oliveira Marques sobre a sua passagem como discente e docente da Faculdade de Letras de Lisboa ${ }^{4}$, apresentados no já longínquo congresso da História da Universidade (1991), e um conjunto de trabalhos de Carvalho Homem ${ }^{5}$. Inclusivamente, estes autores prosseguiram o desenvolvimento da pesquisa no âmbito da história da história, seja com produtos da sua investigação, seja ao nível da orientação, como adiante relevaremos. Mais recentes, do último lustro do século passado, um estudo que resultou de uma dissertação de mestrado, sob orientação de Amado Mendes, apresentada por Avelãs Nunes ${ }^{6}$ à Faculdade de Letras da Universidade de Coimbra, e a hoje incontornável, História da História de Portugal’. Já no nosso século, em textos de caráter mais memorialista e num tom a espaços autobiográfico, as leituras de António de Oliveira ${ }^{8}$ ou de Joaquim Romero de

Congresso "História da Universidade" (No $7^{\circ}$ Centenário da sua Fundação). Volume 1. Coimbra: Comissão Organizadora do Congresso, 1991, pp. 477-498.

3 Matos, Sérgio Campos - O Curso Superior de Letras e a Vulgarização Histórica em Portugal: Projetos em Confronto (1858-1901). In Universidade(s). História. Memória. Perspetivas. Actas do Congresso "História da Universidade" (No $7^{\circ}$ Centenário da sua Fundação). Volume 1. Coimbra: Comissão Organizadora do Congresso, 1991, pp. 367-388.

4 Marques, A. H. de Oliveira - A Universidade do Estado Novo. Memórias de um percurso universitário. In Universidade(s). História. Memória. Perspetivas. Actas do Congresso "História da Universidade" (No $7^{\circ}$ Centenário da sua Fundação). Volume 5. Coimbra: Comissão Organizadora do Congresso, 1991, pp. 431-442.

5 Homem, A. L. Carvalho - Os 25 anos da Faculdade de Letras: passado e presente. In Revista da Faculdade de Letras. II Série. Volume IV, Porto, 1987, pp. 293-307; idem - A história que nos fez e a História que se faz: da primeira à segunda fase da Faculdade de Letras do Porto. In Revista de História do Centro de História da Universidade. Volume XI. Porto, 1991, pp. 227-240; idem - A Idade Média nas universidades portuguesas (1911-1987). Legislação, ensino, investigação. Revista da Faculdade de Letras. II Série. Volume IV, Porto, 1993, pp. 351-361; idem - Os historiadores, esses desconhecidos. In Revista Portuguesa de História. Tomo XXIX, 1994, pp. 33-53; idem - Revistas universitárias de História no Portugal do século XX. In Revista de História das Ideias. História, Memória, Nação. Volume 18. 1996, pp. 339-372.

${ }^{6}$ Nunes, João Paulo Avelãs - A História Económica e Social na Faculdade de Letras da Universidade de Coimbra: o bistoricismo neo-metódico: ascensão e queda de um paradigma historiográfico: 1911-1974. Lisboa: Instituto de Inovação Educacional, 1995. 349 p. ISBN 972-9380-54-6.

7 Torgal, Luís Reis; Mendes, José Maria Amado; Catroga, Fernando - História da História em Portugal. Séculos XIX e XX. Lisboa: Círculo de Leitores, 1996. 719 p. ISBN 972-42-1384-6.

8 Oliveira, António de - As Histórias da Minha Geração. Uma Perspetiva Historiográfica. In Estudos em Homenagem a Luís António de Oliveira Ramos. Porto: Faculdade de Letras da Universidade do Porto, 2004, pp. 83-98. 
Magalhães $^{9}$, ou, mais recente, o estudo de Carvalho Homem, a propósito dos currículos da licenciatura em história, de 1957 e $1968^{10}$, são de nomear porque nos dão interessantes informações. Destaque que não quer, de modo algum, opacizar um conjunto de outros trabalhos, não menos relevantes, de dimensão e âmbito muito diversos, assinados, por exemplo, por Oliveira Marques, Vítor de Sá ou Vitorino Magalhães Godinho ${ }^{11}$ ou, noutro plano, aqueloutros resultantes de dissertações de mestrado, apresentadas às Faculdades de Letras, da Universidade de Coimbra ${ }^{12}$ e de Lisboa ${ }^{13}$. Ainda assim, não é menos verdade que sabemos pouco sobre diversos domínios, onde faltam, por exemplo, estudos sistemáticos sobre a larga maioria dos nossos historiadores e das nossas historiadoras ${ }^{14}$.

9 Magalhães, Joaquim Romero de - Oração de Sapiência proferida na abertura solene do ano letivo: 16 de Setembro de 2009. Coimbra: FEUC, 2009, 16 p.

10 Homem, A. L. Carvalho - Saber positivo e teorização nos primitivos currículos da licenciatura em história (1957 e 1968). História, Revista da Faculdade de Letras da Universidade. IV Série. Volume 1. Porto, 2011, pp. 23-27.

11 Dos trabalhos destes historiadores sobre a historiografia portuguesa, a mero título de exemplo, destaquemos: Godinho, Vitorino Magalhães - Ensaios III. Sobre Teoria da História e Historiografia. Lisboa: Livraria Sá da Costa Editora, 1971; Marques, A. H. de Oliveira - Ensaios de Historiografia Portuguesa. Lisboa: Palas Editoras, Lda., 1988; Sá, Victor de - Notas Sobre o Ensino da História na $1^{\text {a }}$ Faculdade de Letras do Porto. In Revista da Faculdade de Letras do Porto. História. Disponível em U. R. L. http://ler.letras.up.pt/uploads/ficheiros/2046.pdf [Consultada a 2-8-2011].

12 Cf. Torgal, Luís Reis; Mendes, José Maria Amado; Catroga, Fernando - História da História em Portugal. Séculos XIX e XX. Lisboa: Círculo de Leitores, 1996.

13 Dores, H. G. - A História da Faculdade de Letras de Lisboa (1911-1930). Lisboa: Universidade/Faculdade de Letras/Departamento de História, 2008. Dissertação de mestrado. Disponível em U. R. L.: http://repositorio.ul.pt/handle/10451/424 [Consultado em 13-2-2013]; Tavares, L. F. R. - Curso Superior de Letras: Inventário. Lisboa: Universidade/Faculdade de Letras/Departamento de Ciências da Documentação e Informação. 2009. Relatório de Estágio/Mestrado. Disponível em U. R. L.: http://repositorio.ul.pt/bitstream/10451/432/1/21367_ulfl071255_tm.pdf [Consultado em 13-2-2013]; Ainda a dissertação de doutoramento de: Couvaneiro, João L. S. F. - O Curso Superior de Letras (1861-1911). Nos primórdios das Ciências Humanas em Portugal. Lisboa: Universidade/Faculdade de Letras/Departamento de História. Dissertação de doutoramento em História (Especialidade: História Contemporânea). Disponível em U. R. L.: http:// repositorio.ul.pt/handle/10451/7500 [Consultada a 13-2--2013].

14 Cf. Mendes, J. Amado - Desenvolvimento e estruturação da historiografia portuguesa. In Torgal, Luís Reis; Mendes, José Maria Amado; Catroga, Fernando - História da História em Portugal. Séculos XIX e XX. Lisboa: Círculo de Leitores, 1996, p. 161. ISBN 972-42-1384-6. Ainda 
O painel onde nos inserimos encontra-se, de forma incontornável, configurado pela ideia de instituições. O vocábulo Instituição, que terá entrado na língua portuguesa no século XV, compagina dois atos, o de instruir ou educar e o de instituir, reenviando-nos para estabelecimento, criação, instauração. Como se compreende, a sua polissemia ${ }^{15}$ remete-nos para qualquer organismo público ou privado, estabelecido e regulado por leis ou estatutos, englobando, aqui, os estabelecimentos destinados ao ensino e à educação, afinal, as escolas, os institutos, ou associações e sociedades ${ }^{16}$. $\mathrm{Na}$ impossibilidade de, ainda assim, abrangermos a totalidade destas instituições, focalizámos a nossa atenção nas instituições que compaginam a investigação, a divulgação científica e a formação de nível superior, cuja origem, no Portugal Contemporâneo, remonta à segunda metade do século XIX, com a criação do Curso Superior de Letras e que posteriormente se atualiza na iniciativa republicana das faculdades de letras, das diferentes universidades de Coimbra e as, então criadas, de Lisboa e do Porto.

No plano institucional centramo-nos sobre os modelos de cursos de «instrucção superior» em história, entendendo-se por modelo uma representação simplificada do real, construída com base em variáveis selecionadas, com finalidades analíticas e sem qualquer caráter normativo ${ }^{17}$. No ensino da história na Universidade procuramos captar os modelos de formação pelo viés da sua estrutura orgânica, nomeadamente, finalidades e objetivos, componentes de formação e a estrutura curricular, realizando aproximações ao ensino praticado e

assim, destaque-se uma dissertação de mestrado, dedicada a Vitorino Magalhães Godinho: Sousa, J. M. Guedes de - Vitorino Magalhães Godinho: história e cidadania nos anos 40. Lisboa: Faculdade de Letras da Universidade, 2012. Dissertação de mestrado em História (História Moderna e Contemporânea). Disponível em U. R. L.: http://repositorio.ul.pt/bitstream/10451/6905/1/ ulfl122521_tm.pdf [Consultado a 19-2.2013].

15 Correia, Margarita - Homonímia e polissemia - contributos para a delimitação dos conceitos. In Palavras, n. ${ }^{\circ}$ 19, Lisboa: Associação dos Professores de Português. Disponível em U. R. L.: http://www.iltec.pt/pdf/wpapers/2000-mcorreia-homonimia_polissemia.pdf [Consultada a 13-9-2011].

16 Cf. Houaiss, Antônio; Villar, Mauro de Salles - Dicionário Houaiss da Língua Portuguesa. Tomo IV FRE-MER. Lisboa: Círculo de Leitores, 2003, pp. 2109-2110. ISBN 972-42-2809-6

${ }^{17}$ Ferry, G. - Le trajet de la formation: les enseignants entre la théorie et la pratique. Paris: Dunod, 1983. 
às conceções de história e às perspetivas pedagógicas presentes, socorrendo-nos de programas, sumários e manuais quando acessíveis. Intentamos através da compreensão da história docência clarificar dimensões na história ciência, procurando mapear leituras e salientar eventuais (con)sequências resultantes das opções curriculares. O primeiro modelo objeto de análise remonta a 1901, não tanto por nesse sentido apontar o título do Colóquio mas mais por ter constituído o momento de afirmação definitiva do Curso Superior de Letras enquanto instituição de formação científica mas também, a partir dessa reforma, de preparação profissional. Encerramos o nosso trajeto analítico em 1957, concluindo com a reforma que conferiu a plena especialização da formação em história, esboçando assim o trajeto percorrido, pela história docência, a partir do momento em que se configurou a formação em humanidades, de caráter enciclopédico e eclético, compaginando-se o ensino da história com o da filologia e o da filosofia. No período de 1910 a 1957, debruçamo-nos sobre o primeiro modelo de ensino da História, nas Faculdades de Letras, fixado em 1911, génese do curso de ciências histórico-geográficas, sobre o de 1930, da licenciatura em ciências históricas e filosóficas, e o modelo de 1957, aquele que primeiro consagrou a licenciatura em história.

\section{Prolegómenos}

Por iniciativa de D. Pedro $\mathrm{V}^{18}$, em 1858, é criado em Lisboa, o Curso Superior de Letras (CSL), esboço de uma futura Faculdade de Letras, como o próprio rei reconheceria em carta dirigida ao seu ministro da Fazenda ${ }^{19}$,

18 Sobre D. Pedro V, em geral, e as suas preocupações com a instrução, veja-se: Mónica, Maria Filomena - D. Pedro V. Casais de Mem Martins/Rio de Mouro: Círculo de Leitores e Centro de Estudos dos Povos e Culturas de Expressão Portuguesa/Temas e Debates, 2007. Em particular chamamos a atenção para os anexos, onde a autora publica um manuscrito de D. Pedro, existente na Biblioteca da Ajuda, sugestivamente intitulado "Considerações sobre a instrução pública», datado de Fevereiro e Março de 1856, pp. 277-317.

19 Carta de El-Rei D. Pedro V a António José de Ávila, seu Ministro da Fazenda. Memorias da Academia Real das Sciencias de Lisboa. Classe de sciencias moraes, politicas e bellas lettras. Tomo III. Parte II. Lisboa: Typografia da Academia, 1865, p. 24. Transcrita em: Aguilar, Manuel Busquets - O Curso Superior de Letras (1858-1911). Lisboa, 1939, pp. 9-12. 
tendo como preocupação a difusão dos «conhecimentos de literatura, história e filosofia ${ }^{20}$. Ideia que fez caminho em Portugal na centúria de oitocentos na tentativa de criação de Cursos ou de uma Faculdade de Letras, mas cujas origens podemos remontar ao Plano de Instrução Nacional (1799), de Francisco Garção Stockler ${ }^{21}$, e que teve continuidade em propostas e projetos como as Ideias sobre o estabelecimento da Instrução Pública, de Luís Mouzinho de Albuquerque $^{22}$, os projetos de lei de Dias Pegado ${ }^{23}$, de José Maria de Abreu ou o de António José Teixeira ${ }^{24}$. Para responder a desafios de internacionalização, como hoje diríamos, coube a Adolfo Coelho, de resto, seu professor, escrever a primeira monografia do Curso Superior de Letras, resultante de uma encomenda para a exposição Universal de Paris (1900) ${ }^{25}$, iniciativa que repetiria para a exposição Nacional do Rio de Janeiro $(1908)^{26}$. Na década de trinta, constituindo a primeira obra de grande fôlego dedicada ao CSL, encontramos a dissertação de doutoramento apresentada por Manuel Busquets de Aguilar $^{27}$. No campo historiográfico salientem-se os trabalhos de A. H. Oliveira Marques ${ }^{28}$ e Sérgio Campos Matos $^{29}$ já acima referenciados. Noutro

20 Cf. Colecção de leis, regulamentos, portarias e ordens relativas ao Curso Superior de letras. Lisboa: Imprensa Nacional, 1883.

21 Cf. Braga, Teófilo - Historia da Universidade de Coimbra nas suas relações com a instrucção publica portugueza. Tomo IV. Lisboa: Por ordem e na Typographia da Academia Real das Sciencias, 1902.

22 Cf. Torgal, Luís Reis; Vargues, Isabel Nobre - A revolução de 1820 e a instrução pública. Porto: Paisagem Editora, 1984, pp. 323-357.

23 Pegado, Guilherme José António Dias - Projecto de lei da organisação gerál da universidade de Portugal, dedicádo a Nação portuguesa [...]. Coimbra: Na Imprensa da Universidade, 1835.

${ }^{24}$ Cf. Gomes, Joaquim Ferreira - Novos Estudos de História e de Pedagogia. Coimbra: Livraria Almedina, 1986, pp. 67-96.

25 Coelho, F. Adolfo - Le Cours Supérieur de Lettres - mémoire. Paris/Lisbonne: Aillaud \& Cie, 1900.

26 Idem - O Curso Superior de Letras e os cursos de habilitação para o magistério secundário. In Notas sobre Portugal. Volume I. Lisboa: Imprensa Nacional, 1908, pp. 437-447.

27 Aguilar, Manuel Busquets - O Curso Superior de Letras (1858-1911). Lisboa, 1939.

28 Neste domínio particular referimo-nos a: Notícia Histórica da Faculdade de Letras de Lisboa (1911-1961). In Ocidente. N. 79 , agosto-outubro, 1970, pp. 1-74. Republicado: Marques, A. H. de Oliveira - ob. cit., 1988, pp. 123-198.

29 Matos, Sérgio Campos - ob. cit. 
plano, não podemos deixar de assinalar, por essencial ao trabalho de historiadores, o relatório de estágio, realizado no âmbito do curso de mestrado, do Departamento de Ciências da Documentação e Informação, por Lúcia Tavares, onde a autora nos apresenta o inventário do CSL e, entre outros aspetos, descreve o fundo documental resultante das atividades do Curso e as condições de acesso e utilização da referida documentação ${ }^{30}$. Finalmente, no ano transato, uma atualização do olhar historiográfico sobre a instituição, a dissertação de doutoramento, apresentada à Faculdade de Letras, da Universidade de Lisboa, por João Couvaneiro ${ }^{31}$, sob orientação de Sérgio Campos Matos. Neste recente estudo, Couvaneiro compagina a abordagem do ensino das bumanidades, do contexto e das condições em que este ocorre, no âmbito da instituição, com a ação e o percurso dos seus atores, professores e alunos.

O CSL foi criado num contexto em que a História mantinha, no ensino secundário, um lugar subalterno e não constituía um saber autónomo no plano de estudos, surgindo associada à Geografia e à Cronologia. Já nas instituições de ensino superior, emergia como matéria preliminar ou preparatória nas Faculdades de Teologia, Cânones e Leis ou, se quisermos, como propedêutica dos saberes sintético-compendiários ${ }^{32}$, para recolocar a questão, no tempo e nos termos em que foi institucionalizada no ensino superior, pelos Estatutos da Universidade, na época da reforma pombalina, em 1772. De resto, era esta a conceção assumida pelo professor da Faculdade de Direito, Manuel Emídio Garcia, também conhecido pela defesa e divulgação do positivismo em Portugal que, no contexto do debate sobre a criação e localização do CSL, controvérsia a que não foram alheios os interesses da Universidade de Coimbra ${ }^{33}$ mas também preocupações com a existência de um corpo docente

30 Tavares, Lúcia F. R. - ob. cit.

31 Couvaneiro, João L. S. F. - ob. cit.

32 Cf. Mota, Luís - A reforma da Universidade enquanto projeto pedagógico (e social) de formação de elites. Separata da Revista de História das Ideias. Volume 22. Coimbra: Faculdade de Letras, 2001, p. 492.

33 Cf. Matos, Sérgio Campos - O Curso Superior de Letras e a Vulgarização Histórica em Portugal: Projetos em Confronto (1858-1901). In Universidade(s). História. Memória. Perspetivas. Atas 1. Congresso História da Universidade. Coimbra: Comissão Organizadora do Congresso "História da Universidade", 1991, pp. 371-373. 
qualificado, como o próprio rei reconheceria ${ }^{34}$, defendia a ideia da importância dos estudos filosóficos, históricos e literários como preparação para os cursos das faculdades superiores ${ }^{35}$. Prolongando uma tradição que podemos remontar ao século XIII, à Faculdade de Artes que já no período medieval era percebida como uma escola propedêutica para as principais faculdades e que viria a ser extinta precisamente pela reforma pombalina. Nos planos de estudos da Universidade de Coimbra, depois de 1772, saliência para duas disciplinas de história, uma em cada uma das faculdades de Teologia e de Cânones e Leis. No Curso Superior de Letras o ensino da História surgiu associado à Literatura e à Filosofia, tendo o seu currículo conhecido um conjunto de reformas que foram introduzindo, sucessivamente, novas disciplinas (1859, 1877, $1878,1893)$ e outras tantas propostas de alteração do plano de estudo (1867, 1879, 1889) que não passaram disso mesmo e que, nalguns casos, tiveram de aguardar pela reforma de 1901 para virem a ser concretizados.

\section{O Curso Superior de Letras (1901-1911)}

Reforma estruturante, esta de 1901, já definida como radical e positiva ${ }^{36}$ e que constituiu, desde logo, uma extensão e um complemento da reforma do ensino secundário (1895), tendo tido ambas o mesmo protagonista, Jaime Moniz (1837-1917), precisamente professor do Curso Superior de Letras. O CSL aproximou-se, nesta altura, do fácies desejado desde a sua génese, o de uma escola normal para o ensino secundário ou liceal e, a sua reformulação à época, aproximou-o, simultaneamente, do que alguns entendiam ser uma faculdade letras. O preâmbulo da lei não deixava dúvidas quanto às preocupações centrais do legislador. No artigo $1^{\circ}$ explicitava-se, claramente, que o

34 Cf. Carta de El-Rei D. Pedro V a António José de Ávila, seu Ministro da Fazenda. Memorias da Academia Real das Sciencias de Lisboa. Classe de sciencias moraes, politicas e bellas lettras. Tomo III. Parte II. Lisboa: Typografia da Academia, 1865, p. 24. Ver também Aguilar, Manuel Busquets - O Curso Superior de Letras (1858-1911). Lisboa, 1939, p. 12.

35 Cf. Garcia, Manuel Emídio - Importância dos estudos históricos nas ciências jurídicosociais e o ensino da história em Portugal. In O Instituto, volume XIX, n. ${ }^{4}$, 1874, pp. 151-153.

36 Cf. Marques, A. H. de Oliveira - ob. cit., 1988, p. 131. 
CSL tinha por fim habilitar para o magistério no curso e para o magistério das disciplinas de letras e humanidades do plano de estudo dos liceus - geografia, língua latina, língua nacional, língua francesa, língua inglesa e língua alemã, história e filosofia - e para cursos, estudos ou funções públicas que leis ou regulamentos viessem a determinar. Contudo, atribuíam-se, nos termos da lei, outras duas finalidades à instituição, o contributo para o progresso dos diferentes ramos de conhecimento e a sua vulgarização, o mesmo será dizer que o CSL se transformava numa instituição de investigação, divulgação e formação de nível superior ${ }^{37}$. A nova oferta educativa, para além do curso do magistério, passava a incluir um curso geral, um outro de bibliotecário arquivista e um terceiro, de habilitação para a carreira diplomática, dotando o CSL de um caráter prático que lhe conferiu uma utilidade social com repercussões imediatas na sua frequência ${ }^{38}$.

O plano de estudos com onze cadeiras comuns e, pontualmente, algumas cadeiras específicas, no total de catorze, apresenta uma arrumação clássica das humanidades - filologias (clássica, românica e germânica), geografia, história e filosofia - e embora excluindo as ciências sociais emergentes ${ }^{39}$, a abertura assinalada no âmbito da filologia e a criação da área da geografia ${ }^{40}$, antecipava o processo curricular das faculdades de letras. O currículo de cariz semi-enciclopédico possuía um reduzido grau de diferenciação de saberes e não acolhia espaço para subespecializações, nomeadamente no âmbito da história ${ }^{41}$. Ele incluía três cadeiras de história, anuais, em todos os cursos, História Antiga, no $1^{\circ}$ ano, no $2^{\circ}$, História da Idade Média e Moderna e História Pátria, no $3^{\circ}$ ano. O conhecimento histórico é igualmente reforçado em todos os cursos pela criação da cadeira bianual de geografia - Geografia I e II, respetivamente no $1^{\circ}$ e no $2^{\circ}$ ano - e que, segundo o que determinava o legislador, "o estudo da geografia, na parte histórica" deveria ter "por um de seus principais assuntos os

37 Cf. Decreto n. ${ }^{\circ}$, de 24 de dezembro. In Diário de Governo. ‥ 224 , de 28 de dezembro de 1901.

38 Cf. Marques, A. H. de Oliveira - ob. cit., 1988, p. 131.

39 Cf. Nunes, J. P. Avelãs - ob. cit., p. 22.

${ }^{40}$ Cf. Torgal, Luís Reis - Ensino da História. In Torgal, Luís Reis; Mendes, José Maria Amado; Catroga, Fernando - ob. cit., p. 483.

41 Cf. Nunes, J. P. Avelãs - ob. cit., p. 22. 
descobrimentos portugueses» ${ }^{42}$. O curso de habilitação ao magistério incluía, ainda, no seu $3^{\circ}$ ano, a cadeira de História da Pedagogia e em especial da metodologia do ensino a partir do século XVI em diante.

O regulamento de 8 de outubro de 1902, no que se refere a métodos de ensino, previa que o conhecimento, nas disciplinas, fosse transmitido nas suas dimensão teórica e na prática, prevendo lições de uma hora com duas lições semanais por cadeira, com exceção de História Pátria que teria três ${ }^{43}$. A dimensão prática emerge, pontualmente, na realização de excursões, à semelhança das promovidas por Silva Teles, em 1904, à Estremadura e Beira Litoral tendo, por essa ocasião, sugerido a visita a monumentos históricos e à serra de Monchique (Algarve). O método de ensino, pelo menos nas lições, seria o expositivo, sustentado numa história de caráter narrativo e muito dependente da arte oratória do professor que, nas palavras de Aguilar, captava o interesse da audiência mais pela eloquência do que pela lição de história. Teria sido Adolfo Coelho que, ao introduzir o sistema de lição científica, o método alemão, contribuiu para tornar o ensino mais eficiente. Na história da instituição, também Jaime Moniz intentara, por via da adoção de livros de texto que permitiriam o acesso a autores e a sua exploração individual, colocar um ponto final nas lições tipo conferência. Contudo, na verdade, a generalidade das apreciações dos professores, por discípulos ou condiscípulos, são a capacidade de atração do público, a fluência da oratória, o método e a lucidez da exposição as características sempre relevadas, em detrimento da apreciação do valor intrínseco da lição ${ }^{44}$. Ainda assim, exceção para a apreciação das aulas de Oliveira Ramos (1862-1931), a quem foi reconhecido que mobilizava métodos científicos modernos no ensino da história ${ }^{45}$. A avaliação prevista no diploma legal, pelo seu lado, ao assentar exclusivamente num exame por cadeira, compaginada com metodologias expositivas de ensino, deixa antever uma preocupação voltada para a capacidade de memorização e a mera reprodução de conhecimentos, distante, de resto, do desenvolvimento da aprendizagem, do estudo e da pesquisa em história.

\footnotetext{
42 Artigo $5^{\circ}$, do decreto n. ${ }^{\circ}$, de 24 de dezembro.

43 Cf. Aguilar, Manuel Busquets - ob. cit., pp. 117-118.

44 Cf. Couvaneiro, João L. S. F. - ob. cit., pp. 135-147.

45 Cf. Aguilar, Manuel Busquets - ob. cit., p. 287.
} 
Quanto aos conteúdos estudados, se em história da pedagogia o nome da própria cadeira apontava uma orientação para a linha de conteúdos - em especial da metodologia do ensino a partir do século XVI em diante -, nas restantes o legislador explicitava que no estudo da história antiga, idade média e moderna, se devia privilegiar a romana e a moderna, em detrimento do período medieval. Já para a história pátria, em consonância com as conceções da escola metódica, que conheceu o seu apogeu no último quartel do século XIX e início do século $\mathrm{XX}^{46}$, indicava a história política, a diplomática, a colonial e as instituições nacionais ${ }^{47}$. O elenco de professores parece indiciar esta asserção. Na cadeira de História Antiga e História da Idade Média e Moderna foram professores Zófimo Consiglieri Pedroso ${ }^{48}$ (1851-1910), entre 1902 e 1904, Manuel Maria de Oliveira Ramos (1862-1931), de 1904 a 1911 e Agostinho José Fortes (1869-1940), no ano letivo de 1910-1911. A lecionação de História Pátria coube a Consiglieri Pedroso de 1903 até ao seu falecimento e, depois, Manuel Oliveira Ramos. Já as aulas de História da Pedagogia foram sempre conduzidas por José Maria de Queirós Veloso (1860-1952), desde o seu início, em 1904, até 1910. As cadeiras de Geografia I e II tiveram como seus professores, Joaquim Teófilo Fernandes Braga (1843-1924), de 1901 a 1904 e de 1904 a 1910, a Francisco Xavier da Silva Teles (1860-1930) ${ }^{49}$.

\section{O curso de ciências históricas e geográficas (1911-1930)}

Criadas no quadro da afirmação do generoso discurso republicano sobre a educação, as faculdades de letras, das universidades de Coimbra e Lisboa, articulavam como finalidades a promoção da alta cultura intelectual com a preparação científica para o exercício de profissões, no domínio das humanidades,

46 Cf. Mendes, J. M. Amado - Desenvolvimento e estruturação da historiografia portuguesa. In Torgal, Luís Reis; Mendes, José Maria Amado; Catroga, Fernando - ob. cit., p. 169.

47 Artigo 5 ${ }^{\circ}$, do decreto n. ${ }^{\circ}$, de 24 de dezembro.

48 Cf. Nunes, L. R. M. - Zófimo Consiglieri Pedroso. Vida, obra e ação política. Lisboa: Faculdade de Ciências Sociais e Humanas/Universidade Nova de Lisboa, 1993. Dissertação de mestrado. Vejam-se particularmente as páginas dedicadas à vertente pedagógica, pp. 81-109.

49 Cf. Marques, A. H. de Oliveira - ob. cit., 1988, pp. 167-168. 
isto é, da filosofia, da filologia, da história e da geografia ${ }^{50}$. A formação de professores para o ensino liceal, as escolas normais primárias e para as recém-criadas escolas primárias superiores, foi transferida para as escolas normais superiores, anexas às respetivas universidades, Coimbra e Lisboa, que exigiam, como pré-requisito, o bacharelato pelas faculdades de ciências e de letras. Atualizando a matriz do CSL, desde logo na oferta educativa, ampliando os cursos para quatro anos e diversificando bacharelatos e graus académicos, as faculdades de letras reproduziam-no quer no plano organizacional, quer ao nível da hierarquização e estruturação dos saberes - visível na configuração dos saberes humanísticos - e, inclusivamente, permanecendo impermeáveis à penetração das ciências sociais ou de outras áreas científicas ministradas noutras faculdades ${ }^{51}$.

As faculdades de letras foram organizadas em seis grupos, constituindo o quarto e o quinto, respetivamente, o de história e o de geografia que, por sua vez, davam origem a uma de cinco secções, a d), de ciências históricas e geográficas - associação disciplinar à semelhança do ensino secundário ou liceal $^{52}$ - que conferia os graus de bacharel e doutor ${ }^{53}$. O currículo, de dupla certificação, revelava, no número de cadeiras, a preponderância da História, que de resto mantinha nas demais secções da faculdade um papel não desprezível, a subordinação da Geografia, assunto que adiante retomaremos, e ao completar-se com cadeiras de outras três secções - filologia românica e clássica e filosofia - e duas ministradas nas faculdades de ciências, assumia um cariz (quási) enciclopédico. A presença de cadeiras cuja justificação aparenta

50 Cf. Decreto de 9 de maio de 1911. Colecção oficial de legislação portuguesa. Volume I. Lisboa, pp. 816-820.

51 Cf. Nunes, J. P. Avelãs - ob. cit., p. 22.

52 Veja-se: Matos, S. C. - História, mitologia e imaginário nacional. A bistória no curso dos liceus (1895-1939). Lisboa: Livros Horizonte, 1990.

53 Para o grau de doutor na secção de ciências históricas e geográficas a legislação prevê provas de história geral, de história de Portugal e de geografia, bem como a defesa de uma dissertação. Cf. Decreto de 9 de maio de 1911. Colecção oficial de legislação portuguesa. Volume I. Lisboa, pp. 816-820. Posteriormente, as alterações introduzidas por legislação de 1918, para efeitos de doutoramento a seção subdivide-se em duas, a de ciências históricas e a de ciências geográficas. Cf. Decreto n. ${ }^{\circ}$ 4:651, de 14 de julho. Diário de Governo. I ${ }^{a}$ Série. N. ${ }^{\circ} 157$, de 14 de julho de 1918. 
passar pelo apoio documental à ciência dominante, as chamadas ciências auxiliares da história, parece autorizar a crescente afirmação do paradigma metódico e positivo.

\section{Quadro 1}

\begin{tabular}{|c|c|c|c|c|c|}
\hline \multirow{2}{*}{ ANO } & \multirow{2}{*}{ DISCIPLINAS } & \multicolumn{2}{|c|}{$10^{\circ}$ SEMESTRE } & \multicolumn{2}{|c|}{$2 .^{\circ} \mathrm{SEMESTRE}$} \\
\hline & & $1 .{ }^{\circ} \mathrm{T}$ & $2 .^{\circ} \mathrm{T}$ & $3 .^{\circ} \mathrm{T}$ & $4 .^{\circ} \mathrm{T}$ \\
\hline $1 .^{\circ}$ & $\begin{array}{l}\text { História antiga } \\
\text { História geral da civilização } \\
\text { Geografia geral } \\
\text { Geografia física } \\
\text { Filologia portuguesa } \\
\text { Filosofia }\end{array}$ & & & & \\
\hline $2 .^{\circ}$ & $\begin{array}{l}\text { História medieval } \\
\text { História de Portugal } \\
\text { Geografia de Portugal e colónias } \\
\text { Curso de desenho aplicado à Cartografia } \\
\text { Etnologia } \\
\text { Filosofia }\end{array}$ & & & & \\
\hline $3 .^{\circ}$ & $\begin{array}{l}\text { História moderna e contemporânea } \\
\text { Epigrafia } \\
\text { Paleografia } \\
\text { Numismática } \\
\text { Diplomática } \\
\text { Geografia política e económica } \\
\text { Literatura Portuguesa } \\
\text { História da filosofia antiga }\end{array}$ & 2 & 3 & 2 & 1 \\
\hline $4 .^{\circ}$ & $\begin{array}{l}\text { História das religiões } \\
\text { Arqueologia } \\
\text { Filologia clássica } \\
\text { HIstória da filosofia moderna } \\
\text { Estética; história da arte }\end{array}$ & & & & \\
\hline
\end{tabular}

O plano de estudos, constante do quadro $1^{54}$, que configurava a proposta de organização sugerida aos alunos pela faculdade de letras, apresentava onze cadeiras do quarto grupo, divididas entre as disciplinas históricas - História Antiga, História Medieval, História Moderna e Contemporânea,

${ }^{54}$ Fonte: Regulamento das Faculdades de Letras. Decreto de 19 de agosto de 1911. Colecção oficial de legislação portuguesa. Volume II. Lisboa, pp. 1617-1634. O número de horas assinaladas reporta-se às lições magistrais previstas no regulamento. 
História Geral da Civilização, História de Portugal e História das Religiões - e as ciências auxiliares da história - Arqueologia, Diplomática, Epigrafia, Numismática e Paleografia. O quinto grupo contribuía com quatro cadeiras, Etnologia, Geografia Geral, Geografia Política e Económica e Geografia de Portugal e Colónias, a que se associavam as lecionadas na faculdade de ciências, Geografia Física e Desenho Cartográfico. O elenco de disciplinas, do plano de estudos, ficava completo com o contributo de outros três grupos, o de filologia clássica - Filologia Clássica -, de filologia românica com Filologia Portuguesa e Literatura Portuguesa, de filosofia - Filosofia I e II, Filosofia Antiga e História da Filosofia Moderna - e com a cadeira anexa de Estética e História da Arte.

O bacharelato em ciências históricas e geográficas, como contraponto da reforma de 1901, não deixa de representar um aprofundamento no âmbito da história, com visibilidade na criação das quatro disciplinas de história geral acrescidas da de História das Religiões e a de História de Portugal, cumprindo, de alguma maneira, os sucessivos pedidos do CSL ${ }^{55}$. Apesar disso foi, contudo, objeto de crítica a opção de dedicar apenas uma cadeira ao estudo da história portuguesa. A crítica proveniente do antigo aluno do Curso Superior de Letras, Fidelino Figueiredo ${ }^{56}$, ideologicamente marcada pela preocupação de desenvolver um ensino de caráter nacional, constituiu um libelo contra a manutenção da matriz generalista e enciclopédica, em detrimento da promoção da necessária especialização essencial para a produção científica original, e que, ainda em seu entender, passaria pela criação de diferentes cadeiras, em diferentes semestres, dedicadas aos estudos históricos e literários portugueses $^{57}$. Lacuna que o legislador pareceu querer colmatar, em parte, quando em 1916 criou as disciplinas bianuais de História de Portugal e de Literatura Portuguesa, e a anual de Geografia de Portugal e Colónias ${ }^{58}$. Existem contudo,

55 Dores, H. G. - ob. cit., pp. 43-45.

56 Cf. Figueiredo, F. - As Faculdades de Letras. Revista de História. Volume 1, 1912.

57 Cf. Dores, H. G. - ob. cit., pp. 45-46.

58 Cf. Lei n. ${ }^{\circ} 639$ de 20 de novembro de 1916. Diário de Governo. I ${ }^{\text {a }}$ Série. N. ${ }^{\circ} 234$, de 20 de novembro. Novas alterações na secção de ciências históricas e geográficas resultaram de legislação de 1918. O novo plano de estudos introduziu novas cadeiras, casos das de Propedêutica histórica (1. ${ }^{\circ}$ ano/1. ${ }^{\circ}$ semestre) e História dos descobrimentos e da colonização portuguesa 
em nosso entender, dois aspetos que aqui merecem ser equacionados, enquanto atenuantes do impacto pela decisão adotada, sem deixar de reconhecer, naturalmente, que a opção por uma matriz generalista e enciclopédica constituiu, obviamente, impeditivo para a especialização e que se revelaria determinante nas opções adotadas a jusante. Na realidade parece-nos plausível, desde logo, reconhecer alguma preocupação com a importância atribuída ao estudo da história nacional quando se conferiu à cadeira de História de Portugal um peso diferente em relação à generalidade das demais (3 horas semanais em vez das 2 horas). Um argumento de outro cariz é a aparente constatação da desarticulação entre a designação da cadeira e os conteúdos que foram objeto de lecionação, tendo por vezes acontecido que ao arrepio de se tratar de uma disciplina de história geral, a linha de conteúdos terá incidido, na verdade, sobre a história portuguesa ${ }^{59}$.

De maior significado consideramos ter sido a introdução das ciências auxiliares da história que se é verdade, não o escamoteamos, pode ser lida como a crescente afirmação de um determinado paradigma historiográfico, não deixa de traduzir uma preocupação de natureza metodológica no sentido de dotar os estudantes de um aparato crítico, essencial ao ofício de historiador, no questionamento dos documentos. Em consonância com esta asserção terá estado o legislador ao prever que o ensino fosse ministrado através de trabalhos práticos e exercícios de investigação científica, para além das lições magistrais. Se estoutras se destinavam à transmissão de conhecimento metódico e completo, já os trabalhos práticos remetiam para exercícios escritos

( $1^{\circ}$ ano $/ 1 .^{\circ}$ semestre), no $4 .^{\circ}$ grupo, e no grupo de geografia, a de Antropogeografia geral (1. ano/1. ${ }^{\circ}$ semestre). De sublinhar, ainda, o reforço da duração de algumas das ditas ciências auxiliares da história, como foi o caso de Paleografia ( $3^{\circ}$ ano), Diplomática ( $4^{\circ}$ ano) e Numismática e esfragística ( $4^{\circ}$ ano), cuja duração passou, respetivamente, para anual e semestrais. Aparentemente, os alunos veem a sua autonomia restringida ao perderem a capacidade de arrumarem as cadeiras ao longo do seu percurso académico. $\mathrm{O}$ artigo $4 .^{\circ}$, do decreto, fixa a vigência do plano de estudos para quatro anos. O destaque final para o desdobramento dos doutoramentos em duas secções, ciências históricas e ciências geográficas. Do exposto devemos sublinhar, no âmbito do bacharelato e particularmente na história, o crescente peso das temáticas da expansão e descobrimentos portugueses e a preocupação em promover alguma reflexão sobre teoria da história. Cf. Decreto n. ${ }^{\circ}$ 4:945, de 1 de novembro. Diário de Governo. I Série. N. ${ }^{\circ}$ 241, 7 de novembro de 1918.

59 Veja-se: Nunes, J. P. A - ob. cit., particularmente as pp. 91-141. 
realizados pelos alunos, fora (a partir de abordagens realizadas na aula) ou dentro da sala de aula, exercícios práticos versando «textos, documentos históricos, objetos arqueológicos e suas reproduções ou modelos apresentados pelo professor». Incluíam-se, aqui, visitas a museus e bibliotecas, excursões simultaneamente de interesse científico e promotoras do crescimento cultural dos alunos, bem como exercícios de investigação científica que deveriam ocorrer no âmbito do Instituto de Estudos Históricos, cuja criação, de resto, a legislação determinava em cada faculdade de letras ${ }^{60}$.

No plano pedagógico e científico, as faculdades de letras, que foram criadas num tempo de crença na capacidade reformadora da escola e na plasticidade humana, atravessada pelos discursos de self-government ${ }^{61}$, pretendiam constituir-se em espaço de autoformação cultural e científica, numa lógica explicitada com clareza por Durkheim na articulação de liberdade e autoridade, onde ser responsável por si próprio, era saber agir pela razão e cumprir com o seu dever ${ }^{62}$. O regulamento de 1911 ilustrava bem este sentido, desde logo, ao entregar aos alunos a liberdade, e a responsabilidade, de escolherem o ano e o semestre em que desejariam frequentar as cadeiras, considerando que as faculdades apenas aconselhavam um plano de estudos, com o objetivo do maior aproveitamento dos alunos. A ausência de precedências acentuava o exercício dessa responsabilidade. Nesta perspetiva se inseriam, também, o caráter facultativo atribuído às lições magistrais, das quais se proibia expressamente a adoção de textos para as lições e se tornava obrigatórias as referências bibliográficas sobre os principais autores, bem como a presença nos trabalhos práticos e nos exercícios de investigação, sublinhando uma importância atribuída à articulação entre a teoria e a prática ${ }^{63}$.

É ineludível o tom de educação nova, visível na procura de um ensino prático e concreto, através do apelo a uma atitude ativa dos estudantes no estudo da história, orientando-os na construção dos seus próprios conhecimentos a

60 Cf. Capítulo II, da organização e natureza dos cursos. Regulamento das Faculdades de Letras. Decreto de 19 de agosto de 1911. Colecção oficial de legislação portuguesa. Volume II. Lisboa, pp. 1617-1634.

61 Cf. Sérgio, A. - Educação Cívica. Lisboa: Livraria Sá da Costa, 1984 [1914].

62 Durkheim, É. - Educação e Sociologia. Lisboa: Edições 70 Lda., 2009, p. 70.

63 Cf. Regulamento das Faculdades de Letras [...] 
partir de observações, experiências e pesquisas, presentes nos exercícios práticos e nos de investigação, onde não falta a mobilização de um conjunto de suportes educativos, como os arquivos, as bibliotecas e os museus. Parece-nos ser essa a essência da mensagem ao país, do conselho escolar da Faculdade de Letras de Coimbra ${ }^{64}$, e que nos permite realizar alguma aproximação ao processo de ensino e de aprendizagem no bacharelato em ciências históricas e geográficas. No domínio das ciências históricas, o conselho considerava, desde o início, que o objetivo era elevar a história à dignidade de ciência procurando conduzir os alunos à compreensão do passado e à sua reconstituição com recurso a "rigoroso processo crítico». Em seu entender, o ensino da história tinha-se caracterizado por ser objetivo, crítico e atualizado. Objetivo, na medida em que as lições ter-se-iam socorrido da análise direta de fontes e de bibliografia específica, traduzindo, mais do que uma «exposição catedrática de resultados", um momento colaborativo e de iniciação aos processos do trabalho científico, em que o professor envolvia o aluno e se afastava de um ensino dogmático. Ao invés de «atrofiar a iniciativa intelectual do aluno» procurava-se despertá-la e criar «Vocações de investigadores». Crítico pois, afirmava-se, o ensino se apoiava numa dupla crítica, a dos documentos e a

64 Importa ter presente que a publicação desta declaração ao país pelo conselho escolar da Faculdade constituía uma tentativa de refutação de acusações, de que tinha sido alvo, e foram produzidas num momento de conflito aberto com o então ministro da Instrução Pública, Leonardo Coimbra, e que esteve na origem da anexação da Faculdade de Letras à Universidade do Porto. No diploma que produz a desanexação da Universidade de Coimbra, o ministro destacava a importância do ensino secundário para a formação do caráter dos jovens e considerava que quem não tivesse conhecimento prático da vida não podia ser bom educador. Depois de comparar os meios sociais de Coimbra e Porto sublinhava a sua convicção das limitações do primeiro ao nível das diferentes atividades socioeconómicas, considerava-o «um meio essencialmente universitário" com o corpo docente embrenhado em "trabalho especulativo". Encerrava os considerandos do decreto emitindo opinião sobre o que entendia serem as preferências da Faculdade de Letras de Coimbra por uma "erudição livresca" ao invés de "especulações originais do espírito moderno» e concluía afirmando que as obras de professores e alunos laureados, daquela instituição, tinham uma "quási completa orientação tomista de forma escolástica" (Decreto . $^{\circ}$ 5:770, de 10 de maio. Diário de Governo. I $^{\text {a }}$ Série. N. ${ }^{\circ}$ 98, 10 de maio de 1919). Datado de 1919, o libelo do conselho escolar da Faculdade de Letras de Coimbra, é posterior às alterações legislativas introduzidas em 1918 no primeiro modelo de formação republicano que aqui analisamos. Assinale-se que essas alterações não só não são tidas em conta na análise como, na sua totalidade ou em parte, ainda não tinham sido operacionalizadas. Cf. A Faculdade de Letras da Universidade de Coimbra ao País. Coimbra: Tipografia França Amado, 1919. 
dos factos, procurando assim, estimular o desenvolvimento científico através do "exercício da crítica heurística» e, pela compreensão e definição do "sentido da evolução histórica», só possível com a crítica dos factos, desempenhar «uma função de cultura». Finalmente, atualizado, na medida em que as referências bibliográficas eram atuais e, simultaneamente, nas aulas se mobilizavam temas e problemas em debate na opinião pública. O ensino da história na faculdade de letras da Universidade de Coimbra, ajustado ao assunto e ao professor, vinha sendo, desde 1910, nos termos das opções descritas, mais em profundidade do que em extensão, no sentido de criar ciência e não se ficar pela anedota, tendo-se optado por educar "possíveis aprendizes de historiadores na severa disciplina do método histórico» em vez de «superficiais declamadores ${ }^{65}$.

A propósito dos exercícios práticos, depois de assegurar que todos se tinham realizado e que os escritos se encontravam arquivados, em conformidade com a lei, sublinhava aquele conselho que, no âmbito da cadeira de História de Portugal, "que mais especialmente se presta com a de Paleografia», os exercícios teriam versado trabalhos originais de investigação, no Arquivo da Universidade ou de história local. A declaração ao país explicitava, ainda, os objetivos que o professor da cadeira perseguia, sublinhando que seriam os de formar investigadores, o de reunir os materiais da história da Universidade e o de reformar a história local. Simultaneamente, na congénere da Universidade de Lisboa, os referidos exercícios concretizaram-se no manuseamento do espólio da Torre do Tombo e da Biblioteca Nacional, muito em função da proximidade geográfica, existente naquela época, entre as três instituições ${ }^{66}$, parecendo corroborar o que em 1919 testemunhava o conselho escolar da faculdade de letras coimbrã. De resto, o mesmo conselho, para além de nos dar conta do material de ensino adquirido ao longo dos oito anos de existência - coleções de mapas e modelos em relevo, o salão de exercícios de investigação histórica, as coleções paleográficas, a galeria epigráfica, a coleção de esfragística e a de numismática romana e portuguesa - destacava o trabalho desenvolvido no domínio científico como sejam, entre outras, as

\footnotetext{
65 A Faculdade de Letras [...], pp. 33-35.

66 Dores, H. G. - ob. cit., p. 43.
} 
publicações de António de Vasconcelos e de Gonçalves Cerejeira, bem como das que se encontravam em vias de publicação, da autoria dos alunos, nomeadamente, o «mapa estatístico da frequência da Universidade, entre a reforma joanina (1537) e a pombalina (1772)", um estudo sobre o Colégio dos Militares e variadíssimas monografias locais ${ }^{67}$. Em jeito de síntese, vale a pena atentarmos nalgumas passagens de uma entrevista concedida por Eugénio de Castro, à época professor da faculdade de letras da Universidade de Coimbra, ao Diário de Notícias de 12 de junho de 1919, em que o poeta professor religa a orientação do estudo da história com os seus professores:

Quanto ao ensino doutrinal, êle é acentuadamente crítico - crítica das fontes e dos factos. Dá disso exemplo o dr. Vasconcelos, sempre ansioso de renovar a matéria dos seus cursos e algo de novo para a história. [...]

$\mathrm{O}$ assistente dr. Cerejeira é o encarregado do curso da história medieval, e, em contacto com o que há de mais moderno, tem feito um ensino de alta crítica, procurando, como resultado nos seus alunos, não tanto saberem história como compreendê-la. [...] O professor dr. Alves dos Santos rege, nesta secção, História moderna e contemporânea. Repugna-lhe ensinar história feita e compraz-se, como despertador de ideias, em descobrir vocações e iniciar os seus discípulos na crítica das fontes originais e narrativas. A sua orientação pode talvez resumir-se em duas palavras: síntese e crítica ${ }^{68}$.

A passagem da entrevista de Eugénio de Castro resume e ilustra bem, em nosso entender, senão a realidade do ensino da história na Faculdade de Letras, da Universidade de Coimbra, pelo menos oferece-nos algumas achegas da leitura e imagem que os professores daquela instituição pretendiam passar para o exterior. À semelhança de sumários, textos das aulas e outros documentos, este - com limitações tal como os demais -, permite-nos captar linhas de compreensão da envolvente pedagógica bem como conteúdos lecionados e a prática letiva dos docentes.

67 A Faculdade de Letras [...], pp. 35-37.

68 Castro, E. - A questão da Universidade. O ensino na Faculdade de Letras. Entrevista do professor dr. Eugénio de Castro. A Faculdade de Letras [...], p. 122. 
A análise do bacharelato em ciências históricas e geográficas torna inevitável um olhar sobre o papel e a atividade da outra ciência, parceira menor na dupla certificação, a geografia. Na verdade, apesar dos esforços desenvolvidos por Silva Teles, professor do CSL e da Faculdade de Letras da Universidade de Lisboa, na opinião de Orlando Ribeiro, o «introdutor do ensino universitário da geografia ${ }^{69}$ entre nós, que identificava o objeto de estudo da geografia nos "fatores naturais da Terra e humanos na sua relação com o meio natural» ${ }^{70}$, próximo das ciências naturais, a geografia seria apartada destas ciências. Por influência do ensino francês em Portugal, a legislação de 1911 arruma-a nos saberes humanísticos e agregada à história, denunciando uma perceção da sua dependência face aos estudos históricos, algo que nem as alterações legislativas de 1916 e 1918 lograriam modificar. Na sua exposição ao país em 1919, o conselho escolar da faculdade de letras da Universidade de Coimbra, no espaço que dedica às «sciencias geograficas", denuncia as consequências deste entendimento subserviente do papel da geografia, denunciando, como consequências, a impreparação dos alunos no final do ensino secundário e o consequente abandono do estudo da geografia. Sem deixar de reconhecer as relações entre ambas as ciências, interrogava-se aquele conselho, se podia «um geógrafo contentar-se com a exposição da sua sciéncia, tão breve quanto seja suficiente para atender ás conexões com a história?». Concluía-se pela necessidade do "ensino da geografia como geografia ${ }^{71}$. A subordinação da geografia à história para além de evidente pelo desequilíbrio patente no número de disciplinas, já acima referido, era ainda, por vezes, visível nos conteúdos lecionados, de que era exemplo a cadeira de Geografia Política e Económica, na Faculdade de Letras da Universidade de Coimbra, que incluía o estudo de "questões como a da partilha de África» ${ }^{72}$, mantendo uma tradição que remonta ao CSL. No plano pedagógico e científico, as cadeiras de geografia, à semelhança das demais

69 Ribeiro, O. - Opúsculos. Volume II. Lisboa: Fundação Calouste Gulbenkian, 1989, pp. 141-161.

\footnotetext{
70 Dores, H. G. - ob. cit., p. 66.

${ }^{71}$ A Faculdade de Letras [...], pp. 42-43.

${ }^{72}$ Idem, ibidem, p. 42.
} 
de história, acentuavam a ligação da teoria com a prática, procurando promover uma atitude ativa no estudo da geografia, conduzindo e orientando os alunos na construção dos seus próprios conhecimentos socorrendo-se dos recursos educativos e da observação do espaço exterior para o efeito, através dos exercícios práticos ou dos de investigação, seja na realização de exercícios sobre coordenadas geográficas, no estudo e realização de perfis longitudinais de rios, colaborando no estudo do clima de Portugal ou, como era referido no caso da Etnologia, na sua iniciação aos métodos e técnicas seguido de observação e estudo dos carateres físicos ${ }^{73}$.

Não devemos perder de vista que, assunto e professor, na linha do que admitia o conselho escolar da faculdade de letras, em 1919, teriam um peso não despiciendo na condução das lições magistrais e dos exercícios. Na verdade, um olhar mais atento sobre as esferas de decisão permite ir um pouco mais longe na apreciação. Ao nível das cadeiras e até de alguns aspetos relativos ao processo de ensino e de aprendizagem, como sejam os diferentes exercícios e a frequência com que estes ocorriam, encontravam o seu nível de decisão no ministério da tutela. Já, por exemplo, a arrumação das cadeiras ao longo do percurso de aprendizagem era, como assinalámos, da exclusiva competência de cada aluno. Como limite, apenas a imposição da duração de 8 semestres antes da sua apresentação a exames de bacharelato. Para além da designação da cadeira e do número mínimo de exercícios por semestre/ano, o professor poderia desenvolver, pelo menos a avaliar pelo que a documentação nos permite conhecer, a sua ação e as suas opções em segura liberdade, nomeadamente, sobre os conteúdos a lecionar. Vale por isso a pena tentar procurar perceber algumas diferenças e, quiçá, semelhanças, através de uma breve análise da cadeira de História de Portugal, opção nossa que foi muito determinada pela natural importância da cadeira e por se tratar daquela em que mais fácil, atendendo a circunstâncias e contextos, seria os professores realizarem investigação e promoverem o envolvimento dos alunos.

Nos anos letivos de 1912-1913 a 1916-1917, coube a António Garcia Ribeiro de Vasconcelos (1860-1941) lecionar a cadeira de História de Portugal, na faculdade de letras da Universidade de Coimbra, tendo colocado como limites

\footnotetext{
73 Idem, ibidem, pp. 38-45.
} 
cronológicos para as suas lições, o período pré-romano e o reinado de D. Duarte. Nos sumários compendiam-se questões metodológicas, temas de história institucional, política e militar e alguns versando história económica e social, tendo adotado o critério dinástico para a periodização, reconhecendo-se a importância atribuída à ação dos "grandes homens", aos "grandes acontecimentos" e às "grandes instituições" ${ }^{74}$. A mesma disciplina, em Lisboa, assegurada por Manuel de Oliveira Ramos (1862-1930), o que se pode supor, com base em pontos das provas orais (1914-1915) e do conhecimento do pensamento do autor através da sua produção científica, é que este se tenha centrado no estudo da medievalidade portuguesa, numa abordagem muito marcada pelo magistério e obras de Alexandre Herculano, onde não terão deixado de estar presentes as teses das origens e da formação de Portugal, a temática das origens étnicas de Portugal, da organização e evolução dos concelhos e a problemática da existência, ou não, de feudalismo em Portugal ${ }^{75}$. Na verdade, mesmo com elevado grau de incerteza, podemos supor uma assinalável diferença entre os conteúdos estudados pelos bacharéis em ciências históricas e geográficas, das duas faculdades de letras do país. Mas regressemos a Coimbra, à Faculdade de Letras na década de vinte, onde Manuel Gonçalves Cerejeira (1888-1977) lecionou História de Portugal dois anos letivos consecutivos. No primeiro, 1926-1927, a sua análise centrou-se nos reinados de D. João II, D. Manuel I e D. João III. Começou por abordar, inicialmente, a situação da Europa e de Portugal, entre 1495 e 1580, e depois, discute as diretrizes da política nacional, da política externa, de questões de cultura e «civilização» portuguesa, de religiosidade, bem como de natureza económica, ao longo destes três reinados mas conferindo centralidade à discussão do "problema judaico» ${ }^{76}$. No ano subsequente, Cerejeira iniciou a lecionação por um

74 Cf. Nunes, J. P. A - ob. cit., pp. 111-112.

75 Cf. Dores, H. G. - ob. cit., pp. 106-110, 133.

76 Cf. Livro de sumários da disciplina de História de Portugal, da Faculdade de Letras, da Universidade de Coimbra (ano letivo de 1926-1927). Transcrito em Nunes, J. P. A - ob. cit., pp. 111-112. A terminologia e a fraseologia ao longo dos sumários levam-nos a conferir algum grau de concordância com a interpretação avançada por Avelãs Nunes no sentido de uma eventual postura de anti-judaísmo de Gonçalves Cerejeira, na regência da cadeira, e que apresentaria uma lógica de justificação e legitimação das políticas de D. João II, D. Manuel I e D. João III neste domínio. 
conjunto de reflexões epistemológicas e metodológicas, apresentando uma conceção metódica e empirista da história. Comentou as principais histórias de Portugal à época - as de Alexandre Herculano, Oliveira Martins e Pinheiro Chagas - e apresentou uma divisão da história de Portugal, segundo um critério estrutural, recusando propostas de periodização assentes somente em "vicissitudes políticas» 77. Concluiu o curso com a análise e caracterização de um período da história de Portugal, incidindo, neste ano letivo, sobre o período que decorre desde o início da reconquista e o surgimento de Portugal como país independente ${ }^{78}$.

Para além do elencar dos conteúdos e da orientação dada na sua exploração, no âmbito da cadeira de História de Portugal, a síntese deduzida permite-nos sublinhar a complexidade do objeto de estudo, bem como reafirmar a importância do conhecimento dos professores e das suas práticas, para a compreensão do ensino da história. Na verdade, a formação dos bacharéis em ciências históricas e geográficas, no âmbito da cadeira de História de Portugal, revelou-se dissemelhante não só entre faculdades de universidades diferentes, mas inclusivamente no âmbito da mesma faculdade onde se registaram diferenças substantivas, seja pelo viés do paradigma historiográfico mais ou menos conscientemente assumido pelos professores, mas particularmente pelas temáticas, assuntos e períodos que convocam, mesmo com assinaláveis, e até surpreendentes, diferenças entre anos letivos ainda que mantendo-se o mesmo professor, como foi o exemplo de Manuel Gonçalves Cerejeira, entre 1926 e 1928. Na verdade, os objetivos gerais da formação - consignados em lei -, eram dotados de elasticidade que lhes permitia acolherem diferenças de especial relevância a esse nível e, paralelamente, as preocupações de uma lógica de curso e de objetivos mais específicos para a formação, aparentavam estar ausentes das tomadas de decisão das faculdades, em geral, e dos professores em particular.

77 Machado, F. F. - História de Portugal. Súmula das lições magistrais de História de Portugal ( $1^{\circ}$ Ano) pelo Exmo. Professor Doutor Senhor Doutor Manuel Gonçalves Cerejeira, no ano lectivo de 1927-1928, na Faculdade de Letras da Universidade de Coimbra. Coimbra: Tipografia da Gráfica Conimbricense, 1928, p. 12. Citado por Nunes, J. P. A - ob. cit., p. 116.

78 Cf. Nunes, J. P. A - ob. cit., pp. 114-120. 


\section{A licenciatura em ciências históricas e filosóficas (1930-1957)}

O novo modelo de formação no domínio das ciências históricas, no âmbito das faculdades de letras, surge num contexto de afirmação definitiva do salazarismo e na emergência da Ditadura Nacional, cuja legitimidade política foi transferida para a educação e o ensino, e se norteou pelo binómio redução e controlo, como forma de conformação de atores e estruturas republicanas, de que a extinção das escolas normais superiores constitui um exemplo. Após uma fase de procura de um rumo a dar ao ensino universitário, em geral, e às faculdades de letras, em particular, visível na publicação de legislação sucessiva ${ }^{79}$, circunstâncias, de resto, semelhantes às experienciadas e já identificadas nos demais níveis de ensino, Gustavo Cordeiro Ramos (1888-1974) almejou publicar, em 193080, a legislação que iria moldar a formação de quadros, no âmbito da história, lato senso, no quarto de século subsequente ${ }^{81}$.

A finalidade do novo diploma, pelo menos a proclamada, foi adequar a legislação às exigências imperativas do Estatuto Universitário, de março de 1929, e, por certo pensando na geografia, como adiante veremos, o

79 As alterações aos Estatutos Universitários determinaram alterações, mais ou menos profundas, na orgânica e currículos das faculdades de letras. Em tempo de Ditadura Militar, a primeira alteração foi subsequente ao novo Estatuto Universitário Português (Decreto n. ${ }^{\circ}$ 12462, de

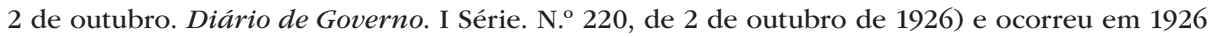
(Decreto n. ${ }^{\circ}$ 12677, de 12 de novembro. Diário de Governo. I Série. N. 220 , de 17 de novembro de 1926), cujas alterações compaginavam a licenciatura em ciências históricas e geográficas com aqueloutra em ciências históricas e filosóficas. Aquando da publicação de novo estatuto universitário (Decreto n. ${ }^{\circ}$ 16623, de 18 de março. Diário de Governo. I Série. N. ${ }^{\circ}$ 62, de 18 de março de 1929), Gustavo Cordeiro Ramos publicaria nova legislação para as faculdades de letras (Decreto n. ${ }^{\circ}$ 17063, de 3 de julho. Diário de Governo. I Série. N. ${ }^{\circ}$ 149, de 3 de julho de 1929). A sua saída do governo precipitaria a revogação da legislação ainda antes do fim do verão e nunca entrou em vigor (Decreto n. ${ }^{\circ}$ 17305, de 5 de setembro. Diário de Governo. I Série. N. ${ }^{204}$, de 5 de setembro de 1929).

${ }^{80}$ De regresso ao ministério da instrução pública seis meses mais tarde, Gustavo Cordeiro Ramos retomou, no diploma de 1930 muito do que tinha definido em julho anterior. Sobre um possível conflito de personalidades com Francisco Xavier da Silva Teles, para além das questões aqui destacadas, veja-se Dores, H. G. - ob. cit., pp. 58-60.

81 Decreto n. ${ }^{\circ}$ 18:003, de 25 de fevereiro. Diário de Governo. I Série. N. ${ }^{\circ} 46$, de 25 de fevereiro de 1930. 
desenvolvimento e consequente reorientação de alguns ramos de ensino. Não se tratava, do ponto de vista do poder político, de uma reforma. O legislador reconhecia-o, $a$ reforma deveria ter como objetivo oferecer condições aos docentes do ensino superior para que estes só se preocupassem apenas com o ensino e a investigação, proporcionando-lhes «uma maior concentração de estudos» e "uma especialização mais efetiva dos seus trabalhos», contudo, essa só chegaria apenas quando estivessem reunidas as «condições económicas e financeiras do País» ${ }^{82}$. As condições para $a$ reforma tardariam e o modelo de formação perdurou 27 anos.

O reconhecimento de que a geografia se tinha alcandorado à «categoria de organização científica autónoma», uma ciência da terra a par da geologia, conferia-lhe um estatuto contraditório, e mesmo incompatível, com a sua posição de ciência auxiliar da história, pelo que se optava pela criação de uma licenciatura em ciências geográficas assumindo-se que se tratava de uma acomodação ao estado dos conhecimentos. Na licenciatura em ciências históricas e filosóficas, esse "conúbio monstruoso», nas palavras de Virgínia Rau ${ }^{83}$, cuja criação, recorde-se, remontava aos inícios da Ditadura Militar ${ }^{84}$, procurou-se um maior equilíbrio e reciprocidade entre o $4^{\circ}$ grupo (ciências históricas) e o $6^{\circ}$ (ciências filosóficas) e simultaneamente retirou-se o seu caráter enciclopédico. O equilíbrio é alcançado com a redução do número de disciplinas do $4^{\circ}$ grupo, nomeadamente, História de Portugal II, Propedêutica da História e História das Religiões e introduzindo três cadeiras semestrais do grupo de ciências filosóficas, História da filosofia em Portugal, Moral e Teoria do Conhecimento. Paralelamente desapareciam as cadeiras anuais de História da Literatura Portuguesa I e II e eram retiradas do plano de estudos a disciplina de Estudos Brasileiros e a cadeira anexa. Já Etnologia foi substituída por Geografia humana. O plano de estudos, constante do quadro 2, apresentava, assim, onze cadeiras do $4^{\circ}$ grupo, sendo sete de história e quatro das ditas ciências auxiliares da história. O grupo de ciências filosóficas contribuía com

82 Idem, ibidem, p. 363.

83 Citada por Marques, A. H. de Oliveira - ob. cit., 1991, p. 438.

84 Cf. Decreto n. 12677 , de 12 de novembro. Diário de Governo. I Série. N. ${ }^{\circ} 220$, de 17 de novembro de 1926. 
nove disciplinas - duas das quais do âmbito da psicologia, ficando o plano de estudos preenchido com a cadeira anexa de Estética e História da Arte e com a disciplina de Geografia Humana.

\section{Quadro 2}

\begin{tabular}{|c|c|c|c|}
\hline ANO & DISCIPLINAS & ANUAL & SEMESTRAL \\
\hline $1 .^{\circ}$ & $\begin{array}{l}\text { História da antiguidade oriental } \\
\text { História da antiguidade clássica } \\
\text { História da filosofia antiga } \\
\text { Geografia humana } \\
\text { Psicologia geral } \\
\text { Epigrafia }\end{array}$ & $\begin{array}{l}A \\
A\end{array}$ & $\begin{array}{l}S \\
S \\
S\end{array}$ \\
\hline $2 .^{\circ}$ & $\begin{array}{l}\text { História medieval } \\
\text { História de Portugal } \\
\text { História da filosofia medieval } \\
\text { Lógica e metodologia } \\
\text { Paleografia e diplomática }\end{array}$ & $\begin{array}{l}A \\
A \\
A \\
A \\
A\end{array}$ & \\
\hline $3 .^{\circ}$ & $\begin{array}{l}\text { História moderna e contemporânea } \\
\text { História dos descobrimentos } \\
\text { e da colonização portuguesa } \\
\text { História da filosofia moderna } \\
\text { e contemporânea } \\
\text { História geral da civilização } \\
\text { Numismática e esfragística }\end{array}$ & $\begin{array}{l}A \\
A \\
A\end{array}$ & $S$ \\
\hline $4 .^{\circ}$ & $\begin{array}{l}\text { História da filosofia em Portugal } \\
\text { Teoria do conhecimento } \\
\text { Psicologia experimental } \\
\text { Moral } \\
\text { Arqueologia } \\
\text { Estética; história da arte }\end{array}$ & $\begin{array}{l}A \\
A \\
A\end{array}$ & $\begin{array}{l}S \\
S \\
S\end{array}$ \\
\hline
\end{tabular}

No domínio da história, as cadeiras suprimidas eram «julgadas menos necessárias» e afirmava-se no diploma que, paralelamente, se procurava "garantir uma mais sólida aprendizagem da história", pelo que se destacava a importância de propiciar aos alunos o contacto permanente com os arquivos e para a utilização das bibliotecas. O arquivo, em particular, era tido como fundamental para a «iniciação dos futuros licenciados nas delicadas operações de reconstituição do passado pelo contacto com o documento vivo dos factos e das tradições", o que compaginado com a extinção da cadeira de Propedêutica Histórica - disciplina 
focalizada em questões de natureza epistemológica, teórica e metodológica denuncia uma conceção mais erudita e metódica de conceber a produção, o ensino e a divulgação da história, onde as questões colocadas pelo historiador às fontes são irrelevantes e se louva o seu apagamento em face destas ${ }^{85}$.

O ensino deveria ser teórico e prático, no primeiro caso, consistiria em lições magistrais e conferências e o segundo, de trabalhos práticos que, sublinhavase, deveriam ser intensificados. A definição da duração das lições magistrais era competência dos conselhos das faculdades, num intervalo de 2 a 3 horas semanais. Os trabalhos práticos poderiam consistir em exercícios escritos ou orais sobre textos ou fontes, investigações e excursões científicas. Os trabalhos práticos de investigação histórica teriam lugar, em Lisboa, no Arquivo Nacional da Torre do Tombo, na Biblioteca Nacional ou na Biblioteca da Ajuda e, em Coimbra, no Arquivo e Museu de Arte da Universidade de Coimbra ${ }^{86}$.

Ensino determinado pela lei e que os conselhos escolares distribuíam, a avaliar por testemunhos de experiências vividas na faculdade de letras da capital $^{87}$, muitas vezes sem docentes em número suficiente e preparados cientificamente para o assegurarem. Vitorino Magalhães Godinho, que ali foi aluno entre 1936 e 1940, considerou que os professores e assistentes eram «mal escolhidos e pouco dedicados», num "ambiente bafiento» com «um ensino no conjunto obsoleto» ${ }^{88}$. A esta apreciação não é alheio o facto de o corpo docente daquela faculdade se ter mantido entre as duas e três dezenas durante

85 Cf. Bourdé, G; Martin, H. - As escolas históricas. Lisboa: Publicações Europa-América, 2012, pp. 93-114.

86 Cf. Decreto n. ${ }^{\circ}$ 18:003, de 25 de fevereiro. Diário de Governo. I Série. N. ${ }^{\text {46, de }} 25$ de fevereiro de 1930 .

87 Cf. Saraiva, J. H. - Álbum de memórias. $3^{a}$ e $4^{a}$ décadas (anos 40 e 40). A década da esperança e o tempo das campanhas. [s.1.]: Edições "Sol», 2007. Não cabe aqui tratar as relações da história com a memória. Vejam-se: Ferreira, A. G.; Mota, L. - Memories of life experiences in a teacher training institution during the revolution. In Paedagogica Historica: International Journal of the History of Education. DOI: 10.1080/00309230.2012.750375. 2013, pp. 1-18 (link http://dx.doi.org/10.1080/00309230.2012.750375); Ferreira, A. G.; Mota, L. - Memória(s) 30 anos depois. (Entre)vistas a pretexto da formação de professores no PREC. In Estudos do Século XX. N. ${ }^{\circ} 11,2011$, pp. 69-85.

88 Godinho, V. M. - Saudade de lutar pelo futuro. Fernando Piteira Santos. In Godinho, V. M. - Ensaios e estudos - compreender o mundo de hoje. Volume II. Lisboa: Sá da Costa: 2010, p. 503-515. Citado por Sousa, J. M. Guedes de - ob. cit., p. 21. 
os anos vinte e cinquenta do século $\mathrm{xx}^{89}$, confrontando-se no último lustro da década de quarenta com um aumento significativo do número de alunos a que se associava a crescente degradação das instalações, no antigo espaço do convento de jesus, no piso inferior do edifício da Academia das Ciências de Lisboa. Na época em que Magalhães Godinho por ali passou, um reduzido número de professores - cerca de seis - asseguravam o serviço docente de história, num ratio de cerca de três a quatro cadeiras por docente, de temas e épocas variadas, de que só poderia resultar na falta de preparação dos professores e conduzir a um ensino generalista ${ }^{90}$. A apreciação de Oliveira Marques, que frequentou os bancos de estudante quinze anos mais tarde, entre 1952 e 1956, em texto marcado pelo pendor memorialista e autobiográfico, não é muito diferente, considerava que as instalações de uma escola do século XVIII não seriam piores que as instalações no piso térreo do convento de jesus e, aos professores, classificava-os como «medíocres ou mesmo francamente maus» ${ }^{91}$. Já sobre os métodos e o estudo, Oliveira Marques dá-nos conta que na época não existiam sebentas na faculdade de letras, o que classificava como um aspeto positivo, e que os alunos da licenciatura em ciências históricas e filosóficas estudavam a partir de apontamentos das aulas e da "vasta» bibliografia, sobre importantes fontes e manuais. Na sua maioria em francês, referenciando o autor, coleções como a "Que sais je?" ou a "Philosophes", bem como os manuais da "Clio", a "Peuples et Civilisations", da "Histoire Générale» ou da "Évolution de L'Humanité», concluindo que «permitiam colmatar as deficiências do ensino e adquirir conhecimentos sólidos e atualizados» ${ }^{92}$.

Para ambos os reputados historiadores, as vivências e os espaços de socialização criados na faculdade, ainda que por razões e processos muito diversos, parecem ter-se revelado importantes para a sua aprendizagem e formação. Na época de Magalhães Godinho, a "faculdade dos alunos» ${ }^{93}$ constituiu um campo

\footnotetext{
89 Cf. Marques, A. H. de Oliveira - ob. cit., 1988, pp. 158-163.

90 Cf. Sousa, J. M. Guedes de - ob. cit., pp. 19-22.

91 Marques, A. H. de Oliveira - ob. cit., 1991, p. 433.

92 Marques, A. H. de Oliveira - ob. cit., 1991, p. 435.

93 Expressão usada por Mário Soares que foi aluno da Faculdade de Letras naquela época. Soares, M. - Portugal amordaçado. Depoimento sobre os anos do fascismo. Lisboa: Arcádia,
} 1974 , p. 41. 
de aprendizagem, de intervenção e de socialização. Um ambiente marcado por uma cultura de resistência com referências culturais próprias, como foi o caso da imprensa periódica, exemplo disso foram O Diabo, a Seara Nova - António Sérgio constituía uma referência cultural e cívica - ou a tantas vezes efémera imprensa universitária. Os cafés, mas também os protestos e as manifestações dos inícios de quarenta, constituíram espaços de socialização, numa rede social com regras próprias, muitas vezes com ligações políticas a organizações clandestinas, como era o caso do PCP. Este ambiente propiciou, a toda uma geração de alunos, uma importante dimensão formativa, vincadamente autodidata e que, de resto, Godinho não deixou de destacar ${ }^{94}$. De outro teor e natureza são as asserções de Oliveira Marques, para quem as aprendizagens se prolongavam para além das aulas, sendo frequentes os contactos informais entre professores e alunos - «um aspeto positivo do ensino» -, passeando nas ruas ouvindo os "mestres», em deslocações a casas destes ou em tertúlias de café, existindo professores "deficientes na cátedra" que se revelavam "excelentes conversadores e bons pedagogos» fora do espaço escolar. No cômputo global, ainda assim, Oliveira Marques, como que responsabilizando o «conúbio monstruoso", chega a comparar as onze cadeiras de história que realizou com as cerca de vinte e uma da licenciatura em história, nos alvores da década de noventa do século passado, considerando que a preparação era deficiente, particularmente nos temas de história e história da filosofia dos séculos XVI a $\mathrm{XX}$ - reduzidas a uma cadeira em cada ramo - e igualmente em história de Portugal, sendo comum o que considerava ser "o vício do começar pelo princípio", resultando no conhecimento dos "primeiros tempos de cada período considerado, com ignorância total dos médios e derradeiros" ${ }^{95}$, de que resultava invariavelmente, dizia, que os programas nunca se cumprissem.

94 Cf. França, J.-A. - Memórias para o ano 2000. Lisboa: Livros Horizonte, 2001; Godinho, V. M. - ob. cit.; Serrão, J. - Os anos 40. Condicionalismos gerais. Um testemunho. Uma aproximação. In Os anos 40 na Arte Portuguesa. A cultura nos anos 40. Colóquios. Volume VI. Lisboa: Fundação Calouste Gulbenkian, 1982, pp. 13-31; Soares, M. - ob. cit., pp. 35-59. Como salienta Guedes de Sousa os textos de José-Augusto França, Joel Serrão, Mário Soares e Vitorino Magalhães Godinho apontam para a importância do autodidatismo das suas formações. Sobre as ideias que aqui explanamos veja-se: Sousa, J. M. Guedes de - ob. cit., pp. 22-25.

95 Idem, ibidem, pp. 433-436. 
$\mathrm{O}$ "vício de começar pelo princípio» pode ajudar a explicar a razão pela qual, em momentos em que a história de Portugal tinha caráter bianual, os programas se mantiveram quase exclusivamente no período medieval $^{96}$, obrigando-nos a complexificar a nossa análise, constatando que a simples duplicação das cadeiras de história pátria não significaria, necessariamente, o alargamento do período histórico estudado, para o que concorreria entre outros aspetos, nesta época, o caráter subversivo que o Estado Novo conferia ao estudo da história contemporânea e a que também não seria alheio o posicionamento epistemológico e metodológico da larga maioria do corpo docente, perfilhando o paradigma historicista metódico e positivo. Do ponto de vista global da formação em História de Portugal, a análise não pode ser confinada a uma mera questão de número de disciplinas, tanto mais, como salienta Reis Torgal, a introdução da dissertação para conclusão da licenciatura, implicaria, na maioria das vezes, o desenvolvimento de um processo de investigação no âmbito, precisamente, da História de Portugal ${ }^{97}$. No quadro disciplinar, em Coimbra, neste segundo período de vigência da licenciatura em ciências históricas e filosóficas, nos anos letivos de 1931-1932 a 1955-1956, o programa incluía o estudo da formação da nacionalidade até à crise nacional, a crise de 1383-1385, com predomínio dos "grandes acontecimentos e personalidades", da "história institucional, política e militar e da história da cultura erudita ${ }^{98}$. Na década de cinquenta do século $\mathrm{xx}$, em Lisboa, no âmbito da mesma disciplina, abordar-se-iam, fundamentalmente, temas como "as origens, o condado portucalense, a reconquista e, às vezes, a crise de 1383-1385"99. A avaliar pelas fontes e testemunhos que aqui mobilizamos parece ter existido uma proximidade, aparente ou não, entre os conteúdos estudados em ambas as universidades, ainda assim, não é desprezível a importância e a autonomia que cada docente teria no tratamento dos mesmos. Sobre o papel de cada

96 Nunes, J. P. A. - ob. cit., p. 112.

97 Cf. Torgal, Luís Reis - Ensino da História. In Torgal, Luís Reis; Mendes, José Maria Amado; Catroga, Fernando - ob. cit., p. 484.

98 Cf. Nunes, J. P. A. - ob. cit., p. 123.

99 Marques, A. H. de Oliveira - ob. cit., 1991, p. 434. 
docente e a sua importância para a formação do corpo discente escrevia Oliveira Marques:

Um bom elenco de professores poderia, eventualmente, melhorar a fraca preparação de base, insistindo em aspectos metodológicos e leccionando, quer visões de conjunto quer um ou dois temas monográficos exemplificativos. Mas não sucedia assim ${ }^{100}$.

Dez anos antes, durante a sua efémera passagem pela Faculdade de Letras de Lisboa como professor extraordinário contratado, Godinho, pelo seu empenho nas tarefas pedagógicas, pelos seus métodos e pela sua produção científica teria satisfeito os quesitos de Marques. Na linha da dispersão que já assinalámos na distribuição de serviço docente, Godinho lecionou História da Antiguidade Oriental, História da Antiguidade Clássica, História Medieval, Numismática e esfragística, as aulas práticas - e por falta de professor, igualmente as teóricas - de História dos descobrimentos e da colonização portuguesa e de História moderna. Como destaca o estudo de Guedes de Sousa, nomeadamente a partir das fichas de sumário das aulas de Magalhães Godinho, este privilegiou a leitura e o comentário de fontes procurando desenvolver o sentido crítico em relação às fontes históricas e, simultaneamente, estimulando os alunos a abandonarem o papel passivo na sala de aula, apontando, por um lado, a necessidade de interrogar a fonte e desenvolver a capacidade de interpretação e, por outro, privilegiando a apresentação de trabalhos ao longo das aulas. Recorrendo a aulas de discussão sobre um tema dado, Godinho promoveu a reflexão sobre a história e a historiografia, instigando o debate em torno do ofício de historiador. Uma das vertentes características do seu magistério foi precisamente o estimular a reflexão epistemológica e metodológica da história. De salientar, ainda, a consonância entre a atividade docente e a produção científica do historiador. Posicionamento, naturalmente contra-hegemónico, que encerraria com uma saída polémica de Magalhães Godinho da Faculdade de Letras, de que resultou um abaixo-assinado dos alunos contra a sua saída,

100 Idem, ibidem, p. 433. 
com a não renovação do seu contrato por razões que fontes recentes parecem apontar para justificações de natureza político-ideológica, como o historiador defendeu ${ }^{101}$.

\section{Quadro 3}

\begin{tabular}{|l|l|}
\hline \multicolumn{1}{|c|}{ INSCRIÇÕES NAS DISCIPLINAS } & \multicolumn{1}{c|}{ PRECEDÊNCIAS } \\
\hline História medieval & História da antiguidade oriental \\
\hline História moderna e contemporânea & História medieval \\
\hline História da filosofia medieval & História da filosofia antiga \\
\hline $\begin{array}{l}\text { História da filosofia moderna } \\
\text { e contemporânea }\end{array}$ & $\begin{array}{l}\text { História da filosofia antiga } \\
\text { História da filosofia medieval }\end{array}$ \\
\hline
\end{tabular}

Já no domínio da avaliação, a legislação revelava-se particularmente normativa. Estabelecia um conjunto de precedências (quadro $3^{102}$ ) e definia, para admissão a exame final, a presença em dois terços do total de lições magistrais, igual número em sessões de trabalhos práticos e como média de frequência nestes últimos, no mínimo, de dez valores. Já a classificação de catorze valores nos trabalhos práticos determinava a dispensa de exame. $\mathrm{O}$ exame, realizado por disciplina, constava de prova escrita (escrita e oral para os alunos voluntários) que deveria exigir "duas séries de trabalhos: respostas a um questionário e elaboração de um exercício sobre um ponto do programa” ${ }^{103}$. O grau de licenciado adquiria-se por meio de prova de defesa de uma dissertação e provas nas disciplinas de História geral, História de Portugal, Psicologia experimental, História da filosofia moderna e contemporânea e Lógica e metodologia. No penúltimo ano de vigência deste modelo, o então aluno Oliveira Marques, realizou quatro exames orais e um exame escrito de Lógica e metodologia, sobre pontos fixados antecipadamente mas cujos temas não tinham sido tratados ao

101 Cf. Sousa, J. M. Guedes de - ob. cit., pp. 25-41; 158.

102 Cf. Decreto n. ${ }^{\circ}$ 18:003, de 25 de fevereiro. Diário de Governo. I Série. N. ${ }^{46}$, de 25 de fevereiro de 1930 .

103 Idem, ibidem. 
longo do curso. A propósito da apresentação e defesa da dissertação, Oliveira Marques testemunha:

Escolhi um tema vastíssimo, A Sociedade em Portugal nos séculos XII a XVI, mas tive a sorte de encontrar documentação de arquivo praticamente inédita que ajudou a compensar o absurdo do tema e a má orientação recebida ${ }^{104}$.

O testemunho permite-nos assinalar, reforçando ideia já expressa, que, neste caso, a temática da dissertação incidiu sobre a história de Portugal como, provavelmente, terá acontecido na maioria das vezes. Por outro lado, ilustra o trabalho de arquivo solicitado aos estudantes de ciências históricas e filosóficas, no âmbito da história, e que permitiu a Oliveira Marques utilizar «documentação de arquivo praticamente inédita». O seu curto comentário leva-nos a destacar estoutro tema, o da orientação, muito relevante e significativo no que refere à produção, reprodução e divulgação da história, na medida em que nos permitiria aceder a processos e formas de construção do conhecimento histórico, e sobre a qual o conhecimento é limitado ou inexistente. Seria interessante desenvolver uma investigação nesta área, pois sob ela, impende o risco de perda definitiva, um elemento que poderia revelar-se importante para a compreensão da fabricação da história, traço essencial da memória coletiva. Situação tanto mais premente, quando pensamos em épocas mais recuadas, na medida em que, muito provavelmente, por ausência de registos escritos, só a recolha de testemunhos orais permitirá captar essa dimensão da formação em história, com base em relatos da orientação das dissertações (licenciatura e doutoramento para este período).

Entre 1930 e 1957, o título de doutor na secção de ciências históricas era conferido ao licenciado que fosse aprovado nas provas de História geral, História de Portugal e História dos descobrimentos e da colonização portuguesa e realizasse, simultaneamente, a defesa de uma dissertação que constituísse um trabalho original e expressamente para o efeito, versando naturalmente as temáticas do âmbito da secção ${ }^{105}$. Ora, as dissertações, de licenciatura e de

104 Marques, A. H. de Oliveira - ob. cit., 1991, p. 437.

105 Cf. Decreto n. ${ }^{\circ}$ 18:003, de 25 de fevereiro. Diário de Governo. I Série. N. ${ }^{46}$, de 25 de fevereiro de 1930 . 
doutoramento, constituem um indicador da produção científica universitária e, no caso de se revelarem inovadoras, parece-nos que seria relevante compreender o seu processo de construção e desenvolvimento bem como constrangimentos e condicionalismos ou apoios relevantes, dimensões importantes para captar o ambiente e o trabalho universitário, neste caso particular, no domínio da história. Neste período e contexto, com caráter renovador, já têm sido destacados os contributos de Virgínia Rau (1907-1973) e de Jorge Borges de Macedo (1921-1996) ${ }^{106}$.

Destaquemos aqui Virgínia Rau, com caráter paradigmático, pelo facto de ter realizado todo o seu percurso no quadro deste modelo de formação. Medievalista, Rau desempenhou papel relevante na renovação metodológica da história, em Portugal, e desde cedo terá tido contactos com o movimento de transformação da historiografia francesa, liderado por Marc Bloch e Lucien Fèbvre, durante uma viagem de estudo na Europa, que terá tido início em 1927, com permanências em França e na Alemanha. Autora, de vasta bibliografia, desenvolveu estudos pioneiros no âmbito da história económica e social nomeadamente, sobre o Antigo Regime. Frequentou a Faculdade de Letras de Lisboa, de 1939 a 1943, tendo concluído com a dissertação de licenciatura, hoje um clássico, intitulada Subsídios para o estudo das feiras medievais portuguesas ${ }^{107}$. Doutora em 1947, com a dissertação Sesmarias Medievais Portuguesas ${ }^{108}$, foi professora extraordinária e obteve a cátedra em 1952. A sua obra é sustentada numa sólida base documental, com recurso à análise quantitativa, em que emerge uma preocupação em articular o económico e social com fatores de diversa ordem, denunciando uma atualização metodológica, visível no entendimento e empenho na construção de uma história global ${ }^{109}$.

106 Cf. Mendes, J. M. Amado - A renovação da historiografia portuguesa. In Torgal, Luís Reis; Mendes, José Maria Amado; Catroga, Fernando - ob. cit., pp. 277-344; Rau, Virgínia - Estudos sobre história económica e social do Antigo Regime. Introdução e organização de José Manuel Garcia. Lisboa: Editorial Presença, 1984; Macedo, J. Borges de - Itinerário de uma vida pública, cultural e científica. Lisboa: Edições Colibri, 1991.

107 Lisboa: Editorial Presença, 1983 [1943].

108 Lisboa: Faculdade de Letras da Universidade, 1946. Dissertação de doutoramento.

109 Cf. Mendes, J. M. Amado - A renovação da historiografia portuguesa. In Torgal, Luís Reis; Mendes, José Maria Amado; Catroga, Fernando - ob. cit., pp. 294-297; Rau, Virgínia - ob. cit., 1984. 


\section{A licenciatura em história (1957-1968)}

A nova estrutura de estudos humanísticos para as faculdades de letras surgiu num contexto de mudança estrutural da formação social portuguesa (demográfica, económica e social) e de ajustamento do papel de Portugal no mundo, em face das transformações ocorridas após 1945. Sem perder de vista a preocupação da inculcação ideológica, o ensino emergia, agora, investido da função de contribuir para o crescimento e modernização económica, num ambiente de procura otimista da educação, através da preparação de mão-de-obra qualificada. Francisco de Paula Leite Pinto, à data Ministro da Educação Nacional (1955-1961), cuja ação, a par com o seu antecessor, Pires de Lima (1947-1955), foi responsável pela mudança de orientação da política educativa, articulou a preocupação com o planeamento educativo, visível na participação de Portugal no Projeto Regional do Mediterrâneo, com um discurso de generalização da educação, sintonizado com a ideologia políticoeducacional própria do desenvolvimento capitalista europeu, acomodando o ocedeísmo a Portugal ${ }^{110}$.

O preâmbulo do decreto começava por considerar que a estrutura dos estudos humanísticos se mantinha, genericamente, a estabelecida em 1911. Salientava-o, especificamente, referenciando o plano de estudos, o elenco das disciplinas e o regime docente. Contudo, no entender do legislador, a evolução das ciências do espírito, mobilizando aqui uma classificação das ciências que se filiava em Wundt e fora a utilizada precisamente na arrumação das ciências em 1911, considerando que a evolução, em termos de métodos, de recursos - bibliográficos e instrumentais - e de ramificação do campo do saber, exigiam, naquele momento, a especialização. Sem perder de vista o caminho percorrido, considerava que o campo das humanidades, lato senso, em termos institucionais, estava "longe de ser atualizado e eficiente», quer fosse no domínio do ensino ou no da investigação, o que tornava a renovação das faculdades de letras num «dos mais urgentes problemas nacionais»,

110 Cf. Mota, L. - A Escola do Magistério Primário de Coimbra (1942-1989). Entre Ideologia, Memória e História. Tomo I. Coimbra: Faculdade de Letras da Universidade, 2006. Dissertação de doutoramento. Veja-se particularmente o ponto 2, do capítulo II, pelo sentido da análise e pelas referências bibliográficas de que a interpretação é devedora, pp. 119-191. 
pelo que se impunha a reforma da sua "Lei Orgânica». A missão destas faculdades passaria a ser a de formar especialistas mas acautelavam-se os limites dessa especialização, esta teria de ser compaginada com a tradição cultural universitária e integrada numa ampla formação cultural, limitando o tecnicismo e o consequente cercear de horizontes. Acometiam-se-lhes três finalidades, desde logo, a formação de uma elite em humanidades, de «um escol» na retórica do diploma, a preparação profissional, em especial, de professores do ensino secundário, em geral, e liceal, muito em particular, mas também de peritos para outras áreas da vida cultural e, finalmente, o treino para a investigação científica no domínio das diferentes disciplinas de letras. No âmbito deste quadro analítico discutiam-se «os grandes inconvenientes» do regime de estudos definido em 1930, para se concluir pelo sentido e alcance da reforma das faculdades de letras que consignava modificações em diferentes planos, desde o organograma da faculdade e no quadro das disciplinas, nos planos das licenciaturas, no regime de frequência, no regime de exames - incluindo o ato de licenciatura e das provas de doutoramento ${ }^{111}$.

Considerando a multiplicidade e a heterogeneidade das disciplinas dividiam-se as Faculdades de Letras em duas secções, ciências filológicas e ciências históricas, geográficas e filosóficas, que por sua vez eram constituídas por seis grupos, sendo o de história o $4^{\circ}$ grupo, existindo um conjunto de cadeiras anexas - História do Cristianismo (anual), em Coimbra, História da Música e Língua Hebraica (bianual), e em Lisboa, Estudos Camonianos (anual) e Língua Árabe (bianual) - e quatro disciplinas de história da cultura, catalogadas como não agrupadas - clássica, medieval, moderna e portuguesa. Estas últimas constituiriam a charneira da especialização. O decisor político, com base no que considerava ser a avaliação da experiência, ilustrada nos «inconvenientes pedagógicos», bem como o desejo de uma «maior especialização" e uma "mais eficiente» preparação - que implicaria, só por si, o aumento de um número de disciplinas - determinava a criação de uma licenciatura em história e uma outra em filosofia. Contudo, o sentimento de

111 Decreto n. ${ }^{4} 4341$, de 30 de outubro. In Diário do Governo. I Série. N. ${ }^{o}$ 246, de 30 de outubro de 1957. 
que era "tão precisa ao historiador a formação filosófica como o saber histórico ao especialista de filosofia", o legislador optou por criar quatro cadeiras de história da cultura de âmbito "filosófico e historiográfico", alcançando o que considerava ser uma situação equilibrada ${ }^{112}$.

\section{Quadro 5}

\begin{tabular}{|c|c|c|c|c|c|c|c|c|c|c|c|}
\hline \multirow{3}{*}{ ANO } & \multirow{3}{*}{ DISCIPLINAS } & \multicolumn{2}{|c|}{$1 .^{\circ}$ ANO } & \multicolumn{2}{|c|}{$2 .^{\circ}$ ANO } & \multicolumn{2}{|c|}{$3 .^{\circ}$ ANO } & \multicolumn{2}{|c|}{$4 .^{\circ}$ ANO } & \multicolumn{2}{|c|}{ 5. ${ }^{\circ}$ ANO } \\
\hline & & $1 .^{\circ} \mathrm{S}$ & $2 .^{\circ} \mathrm{S}$ & $3 .^{\circ} \mathrm{S}$ & $4 .^{\circ} \mathrm{S}$ & $5 .^{\circ} \mathrm{S}$ & $6 .^{\circ} \mathrm{S}$ & $7 .^{\circ} \mathrm{S}$ & $8 .^{\circ} \mathrm{S}$ & $3 .^{\circ} \mathrm{S}$ & $4 .^{\circ} \mathrm{S}$ \\
\hline & & \begin{tabular}{|l|l|}
$\mathbf{T}$ & $\mathbf{P}$ \\
\end{tabular} & \begin{tabular}{l|l|}
$T$ & $P$ \\
\end{tabular} & \begin{tabular}{|l|l|}
$T$ & $P$ \\
\end{tabular} & \begin{tabular}{|l|l|}
$\mathbf{T}$ & $\mathbf{P}$ \\
\end{tabular} & \begin{tabular}{l|l|}
$\mathbf{T}$ & $\mathbf{P}$ \\
\end{tabular} & \begin{tabular}{|l|l|}
$T$ & $P$ \\
\end{tabular} & \begin{tabular}{|l|l|}
$\mathbf{T}$ & $\mathbf{P}$ \\
\end{tabular} & \begin{tabular}{|l|l|}
$T$ & $P$ \\
\end{tabular} & \begin{tabular}{|l|l|}
$T$ & $P$ \\
\end{tabular} & \begin{tabular}{|l|l}
$\mathbf{T}$ & $\mathbf{P}$ \\
\end{tabular} \\
\hline $1 .^{\circ}$ & $\begin{array}{l}\text { Teoria da Hlstória } \\
\text { Pré-História } \\
\text { História da Antiguidade Oriental } \\
\text { História da Civilização Grega } \\
\text { Paleografia e Diplomática } \\
\text { Introdução à Filosofia }\end{array}$ & \begin{tabular}{ll|}
2 & 2 \\
2 & 2 \\
2 & 2 \\
- & - \\
2 & 2 \\
2 & 2
\end{tabular} & $\begin{array}{ll}2 & 2 \\
2 & 2 \\
- & - \\
2 & 2 \\
2 & 2 \\
2 & 2\end{array}$ & & & & & & & & \\
\hline $2 .^{\circ}$ & $\begin{array}{l}\text { História da Civilização Romana } \\
\text { História da Cultura Clássica } \\
\text { (disciplina não agrupada) } \\
\text { Arqueologia } \\
\text { Hsitória da Arte } \\
\text { Epigrafia } \\
\text { Numismática } \\
\text { Disciplina de opção }\end{array}$ & & & $\begin{array}{ll}2 & 2 \\
2 & 1 \\
2 & 2 \\
2 & 2 \\
2 & 2 \\
- & - \\
- & -\end{array}$ & $\begin{array}{ll}2 & 2 \\
2 & 1 \\
& \\
2 & 2 \\
2 & 2 \\
- & - \\
2 & 2 \\
- & -\end{array}$ & & & & & & \\
\hline $3 .^{\circ}$ & $\begin{array}{l}\text { História da Idade Média } \\
\text { História da Cultura Medieval } \\
\text { (disciplina não agrupada) } \\
\text { História de Portugal I } \\
\text { História da Arte Portuguesa } \\
\text { e Ultramarina } \\
\text { Disciplina de opção }\end{array}$ & & & & & \begin{tabular}{ll|}
2 & 2 \\
2 & 1 \\
2 & 2 \\
2 & 2 \\
- & -
\end{tabular} & $\left|\begin{array}{ll}2 & 2 \\
2 & 1 \\
2 & 2 \\
2 & 2 \\
- & -\end{array}\right|$ & & & & \\
\hline $4 .^{\circ}$ & $\begin{array}{l}\text { História Moderna e Comtemporânea } \\
\text { História da Cultura Moderna } \\
\text { (disciplina não agrupada) } \\
\text { História de Portugal II } \\
\text { História da Expansão Portuguesa } \\
\text { História do Brasil } \\
\text { Disciplina de opção }\end{array}$ & & & & & & & $\left|\begin{array}{ll}2 & 2 \\
2 & 1 \\
2 & 2 \\
2 & 2 \\
- & - \\
- & -\end{array}\right|$ & $\begin{array}{ll}2 & 2 \\
2 & 1 \\
& \\
2 & 2 \\
2 & 2 \\
2 & 2 \\
- & -\end{array}$ & & \\
\hline $5 .^{\circ}$ & $\begin{array}{l}\text { História da Cultura Portuguesa } \\
\text { (disciplina não agrupada) } \\
\text { História do Cristianismo } \\
\text { (cadeira anexa) } \\
\text { Disciplina Seminário }\end{array}$ & & & & & & & & & $\begin{array}{ll}2 & 2 \\
2 & 2 \\
- & -\end{array}$ & $\begin{array}{ll}2 & 2 \\
2 & 2 \\
- & -\end{array}$ \\
\hline
\end{tabular}

112 Idem, ibidem. 
O plano de estudos, constante do quadro $5^{113}$, apresenta uma alteração na duração do ciclo de estudos, passando a licenciatura em história a ter a duração de cinco anos. No que se refere às cadeiras, observa-se um claro reforço da formação e das disciplinas do grupo de história (cerca de 61,5\% do plano de estudos, se se considerarem apenas as cadeiras do $4^{\circ}$ grupo e sem incluir o seminário), num total de dezasseis sendo que dez eram anuais, uma bianual História de Portugal I e II - e cinco semestrais ${ }^{114}$. Com exceção da Introdução à Filosofia, do $6^{\circ}$ grupo, e da generalidade das opções disponíveis, as demais entravam na distribuição de serviço do $4^{\circ}$ grupo. O plano de estudos contemplava, ainda, as quatro disciplinas não agrupadas, as histórias da cultura e uma cadeira não anexada - História do Cristianismo, ou seja, vinte e duas disciplinas encontravam-se pré-definidas, a que acresciam mais três opções a realizar no $2^{\circ}, 3^{\circ}$ e $4^{\circ}$ ano, e disponibilizadas de entre um conjunto especificamente estabelecido para a licenciatura em história (quadro $6^{115}$ ). A oferta de opções para a licenciatura em história compunha-se de cadeiras provenientes de todos os grupos da Faculdade de Letras. O plano ficava completo com o curso de seminário, destinado especialmente à orientação das dissertações de licenciatura e ao ensino prático dos métodos de investigação ${ }^{116}$.

Numa análise mais detalhada das transformações ocorridas no sentido da especialização, destaca-se, desde logo, o reforço de História de Portugal e de História da Colonização Portuguesa com as disciplinas de História de Portugal I e II ( $3^{\circ} / 4^{\circ}$ ano), História da Cultura Portuguesa ( $5^{\circ}$ ano), História da Expansão Portuguesa ( $4^{\circ}$ ano) - cuja alteração de designação pode estar relacionada com o quadro político internacional e a adequação do discurso diplomático do Estado Novo ${ }^{117}$-, História do Brasil ( $8^{\circ}$ semestre) e História da Arte Portuguesa e Ultramarina ( $3^{\circ}$ ano). De igual modo, foram reforçadas, no número de disciplinas, a história da arte e a arqueologia. De assinalar a

\footnotetext{
113 Idem, ibidem.

114 Em 1967, por alteração legislativa, as disciplinas anuais de Arqueologia, História da Arte e de História da Arte Portuguesa e Ultramarina, passam a constituir um subgrupo. Cf. Decreto n..$^{\circ}$ 47609, de 27 de março. Diário de Governo. I Série. N. ${ }^{\circ}$ 73, de 27 de março de 1967.

115 Idem ibidem.

116 Idem ibidem.

117 Cf. Nunes, J. P. A. - ob. cit., pp. 84-85.
} 


\section{Quadro 6}

\begin{tabular}{|l|l|}
\hline \multicolumn{2}{|c|}{ DISCIPLINAS DE OPÇÃO PARA LICENCIATURA EM HISTÓRIA } \\
\hline Língua Latina - I e II & Língua Hebraica - I e II \\
\hline Literatura Latina - bienal & Língua Árabe - I e II \\
\hline Literatura Portuguesa - I, II e III & Geografia Humana - bienal \\
\hline Literatura Brasileira & Etnologia Geral \\
\hline Língua Inglesa - trienal & Etnologia Regional \\
\hline Língua Alemã - trienal & História da Filosofia Antiga \\
\hline Língua e Literatura Espanhola & História da Filosofia Medieval \\
\hline $\begin{array}{l}\text { Língua e Literatura Italiana } \\
\text { História da Cultura } \\
\text { e das Instituições Inglesas }\end{array}$ & $\begin{array}{l}\text { História da Filosofia Moderna } \\
\text { e Contemporânea - bienal }\end{array}$ \\
\hline $\begin{array}{l}\text { História da Cultura } \\
\text { e das Instituições Alemãs }\end{array}$ & Estética e Teorias da Arte \\
\hline
\end{tabular}

introdução de uma cadeira, Teoria da História, que versava sobre os aspetos de epistemologia e metodologia da história, ainda que o seu posicionamento, no início do curso ou no fim - para onde foi transferida pelas alterações introduzida pelas alterações de $1968^{118}$-, justifique um questionamento sobre o entendimento do legislador para esta cadeira, se uma abordagem pelo viés metodológico, aparentemente mais consentânea com a arrumação que lhe foi dada em 1957 ou, ao invés, uma proposta de leitura mais focalizada numa "teoria do acontecer histórico»"119. Esta nossa análise não ficaria concluída sem uma referência à História do cristianismo cuja importância resultava de ser obrigatória e estar localizada no $5^{\circ}$ ano, constituindo, em Coimbra, uma espécie de apologia do cristianismo católico ${ }^{120}$, e em Lisboa, revelava-se pouco

118 Cf. Decreto n. ${ }^{\circ}$ 48627, de 12 de outubro. Diário de Governo. I Série. N. ${ }^{\circ}$ 241, de 12 de outubro de 1968.

119 Cf. Homem, A. L. Carvalho - ob. cit., 2011, pp. 23-27. Veja-se, sobre a disciplina de Teoria da História, a análise, com base nos sumários, de Catroga, F. - Luís Ferrand de Almeida e António de Oliveira no ensino de Teoria da História. In Revista Portuguesa de História. Tomo 36. Volume II, 2002-2004, pp. 125-134.

120 Cf. A asserção de Avelãs Nunes tem por base a análise dos livros de sumários. Nunes, J. P. A. - ob. cit., p. 86. 
científica e "muito mais catecismo alargado do que outra coisa» ${ }^{121}$. Assinale-se a manutenção das designadas ciências auxiliares da história, sempre servindo mais este ou aquele período da história, nomeadamente a pré-história e a história da antiguidade, casos da Epigrafia e Numismática, e o período medieval, a Paleografia e Diplomática, constituindo a Arqueologia um veículo de estudo do período charneira entre estes dois, de resto, bem representados no currículo ${ }^{122}$. Constância, muito significativa, foi a manutenção do reduzido espaço concedido à história contemporânea, visível em duas ausências, primeiro de autonomia do estudo do Portugal Contemporâneo, ilustrada pela existência de uma cadeira de história moderna e contemporânea e, depois, na inexistência de uma história da cultura contemporânea em contraponto com as restantes dedicadas à época clássica, medieval e moderna. Um alhear do estudo da época contemporânea, a que não será estranha a aversão intrínseca do regime e da qual não terá descolado o próprio ensino e aprendizagem, como o parecem demonstrar as linhas de conteúdos, nomeadamente as de história de Portugal ${ }^{123}$.

\section{Quadro 7}

\begin{tabular}{|l|l|}
\hline \multicolumn{1}{|c|}{ INSCRIÇÕES NAS DISCIPLINAS } & \multicolumn{1}{c|}{ PRECEDÊNCIAS } \\
\hline História da Civilização Romana & $\begin{array}{l}\text { História da Antiguidade Oriental } \\
\text { História da Civilização Grega }\end{array}$ \\
\hline História da Idade Média & História da Civilização Romana \\
\hline História Moderna e Contemporânea & História da Idade Média \\
\hline História do Brasil & História da Expansão Portuguesa \\
\hline História da Expansão Portuguesa & História de Portugal I \\
\hline História da Arte Portuguesa e Ultramarina & História da Arte \\
\hline
\end{tabular}

121 Cf. Marques, A. H. de Oliveira - ob. cit., 1991, p. 437.

122 Homem, A. L. Carvalho - ob. cit., 2011, p. 24.

123 Cf. Nunes, J. P. A. - ob. cit., p. 87. 
Detenhamo-nos um pouco nas informações disponíveis para as cadeiras de História de Portugal I e II. Na Faculdade de Letras, em Coimbra, a renovação da cadeira, agora bianual, parece ter ficado a cargo de Luís Ferrand de Almeida, no ano letivo de 1958-1959. História de Portugal II terá iniciado o estudo nos antecedentes de 1640 e concluído com o reinado de D. João V, tendo sido abordadas temáticas de história económica e social e história das mentalidades, suportadas por uma bibliografia de diferentes épocas e correntes historiográficas. De 1959 a 1963, a disciplina de História de Portugal I, versou temas desde a formação da nacionalidade à crise do século xıv, sofreu contudo uma redução cronológica no período subsequente (1963-1964 a 1967-1968). A cadeira do $4^{\circ}$ ano debruçou-se sobre a história de Portugal, desde os antecedentes da Restauração ao reinado de D. José I. De igual modo, em Lisboa, em História de Portugal II no final do programa, estudava-se o tempo pombalino, eventualmente, a guerra peninsular ${ }^{124}$. No seu conjunto, a orientação epistemológica e temática surgiam marcadas pelo historicismo neometódico e, como refere Avelãs Nunes, a propósito do espaço dedicado à história económica e social, ele varia, consoante o docente e sem explicação aparente ${ }^{125}$. Esta dimensão constitui, em nosso entender, uma invariante nos diferentes modelos que vimos estudando e que já aqui mencionámos. Ao atribuir, do que podemos avaliar, a esfera de decisão - ou muito desse poder - sobre os conteúdos, exclusivamente ao arbítrio individual de cada docente, não podemos deixar de nos interrogar até que ponto a unidade e a lógica organizadora do plano de estudos não era confrontada com contradições e orientações divergentes contrariando precisamente o que a manutenção das precedências ${ }^{126}$ (quadro 7) poderia deixar supor. Temos no momento, neste campo, mais interrogações do que certezas. O legislador determinava, ainda assim, que os programas das disciplinas deveriam constituir um plano conjunto, a rever pelo menos de três em três anos, proposto pelo conselho escolar e sujeitos a aprovação por despacho ministerial mediante parecer da Junta Nacional de Educação.

124 Homem, A. L. Carvalho - ob. cit., 2011, p. 24.

125 Idem, ibidem, p. 123-124.

126 Fonte: Decreto n. ${ }^{\circ} 41341$, de 30 de outubro. In Diário do Governo. I Série. N. ${ }^{\circ} 246$, de 30 de outubro de 1957. 
No âmbito da licenciatura com a criação de um quinto ano surgiram os cursos de seminário que se destinavam, particularmente, à orientação das dissertações de licenciatura e ao ensino prático dos métodos de investigação. Competiria às faculdades produzir uma proposta de regulamentação que, depois de parecer favorável da Junta Nacional de Educação, seria objeto de despacho ministerial $^{127}$. Em 1961, por portaria, seriam regulamentados os cursos de seminário, anuais, com três horas semanais de trabalho e cujo número dependeria de proposta do diretor da faculdade, ouvido o conselho escolar, e autorizados pelo ministro. A matrícula num seminário revestia-se de caráter obrigatório e, mesmo os alunos voluntários, teriam de marcar presença, pelo menos, num terço das sessões de trabalho. A direção de cada seminário caberia ao professor catedrático - em caso de necessidade a um professor catedrático contratado ou um professor extraordinário - mediante proposta do diretor da faculdade. A dissertação da licenciatura seria orientada pelo diretor do seminário ou por um professor ou assistente por ele designado, sendo o tema uma escolha do aluno, de acordo com o diretor ${ }^{128}$.

Em termos organizacionais, para os alunos ordinários, as aulas teóricas e práticas eram de frequência obrigatória e mais de um terço de faltas determinava a perda de frequência na disciplina. Os elementos de avaliação consistiam na informação sobre os trabalhos práticos, os exames de frequência, de natureza escrita e por semestre, e os exames finais, a terem lugar em junho e julho, compostos por provas escritas, com a duração de três horas, e orais de trinta minutos, quarenta e cinco, no caso das disciplinas bianuais. Os conteúdos objeto de avaliação nos exames de frequência e finais teriam de versar assuntos estudados nas aulas. A licenciatura era concluída com o ato de licenciatura que consistia na defesa de uma dissertação escrita, perante um júri de três elementos, numa prova com a duração de trinta a sessenta minutos ${ }^{129}$. As normas e regras de avaliação denunciam

127 Cf. Decreto n. ${ }^{4} 41341$, de 30 de outubro. In Diário do Governo. I Série. N. ${ }^{\circ}$ 246, de 30 de outubro de 1957.

128 Cf. Portaria n. ${ }^{\circ} 18785$, de 23 de outubro. Diário de Governo. I Série. N. ${ }^{\circ} 246$, de 23 de outubro de 1961.

129 Cf. Decreto n. ${ }^{\circ} 41341$, de 30 de outubro. In Diário do Governo. I Série. N. 246 , de 30 de outubro de 1957. 
que, às faculdades de letras, estava cometida a função de avaliar e certificar a formação adquirida.

As faculdades, pela legislação de 1957, conferiam o grau de doutor em vários domínios, de que destacamos em História e em Arqueologia e História da Arte. As provas de doutoramento eram compostas pela discussão de uma dissertação perante um júri - com a duração de noventa minutos - e dois interrogatórios, com a duração de trinta a sessenta minutos, sobre dois pontos, que no doutoramento em História deveriam versar História Geral e História de Portugal e da Expansão Portuguesa, e do Brasil e, em Arqueologia e História da Arte, as matérias deveriam tratar Arqueologia e História da Arte ${ }^{130}$.

No âmbito do magistério universitário neste período, no plano de renovação historiográfica, seja pelo viés da lecionação de disciplinas, de responsabilidade nos cursos de seminário ou das orientações de dissertações de licenciatura e doutoramento ou na sua arguição, deveremos destacar, a título de ilustração, na faculdade de letras de Lisboa, Jorge Borges de Macedo (1921-1996) e, em Coimbra, José Sebastião da Silva Dias (1916-1994) ${ }^{131}$. Com uma marcante dissertação para a historiografia portuguesa, A situação económica no tempo de Pombal ${ }^{132}$, Borges de Macedo concluiu a licenciatura em ciências históricas e geográficas (1944). Iniciou a sua atividade docente e de investigador universitário, em 1957, e obteve a cátedra em 1969. A sua atividade científica diversificou-se por quatro grandes áreas, história económica e social e biografia, história política e diplomática, história da cultura e teoria da história e historiografia. Para além da diversidade de temáticas, incorporou, desde o início, a teorização e a preocupação explicativa, por contraponto à mera descrição. Na sua investigação mobilizou fontes diversificadas

130 Idem, ibidem.

131 A escolha, com mero sentido ilustrativo, de Jorge Borges de Macedo e de Sebastião Silva Dias justifica-se pela existência de informação disponível. Para além do reconhecido contributo para a renovação historiográfica, início da sua atividade docente, nas respetivas faculdades foi coincidente com o modelo de formação cuja apresentação concluímos. Mobilizamos aqui apenas algumas notas respigadas na História da História de Portugal, Cf. Mendes, J. M. Amado - A renovação da historiografia portuguesa. In Torgal, Luís Reis; Mendes, José Maria Amado; Catroga, Fernando - ob. cit., pp. 297-299 e 304-311.

132 Cf. Macedo, J. Borges de - A situação económica no tempo de Pombal. Alguns aspetos. Lisboa: Moraes Editores, 1982 [1951]. 
e suportada sempre em diferentes correntes historiográficas, nomeadamente, a anglo-saxónica. Atividade que partilhou com o exercício do magistério, tendo contribuído para formar e influenciar academicamente um conjunto vasto de alunos, tanto pela docência como pela orientação/arguição de dissertações. Silva Dias teve formação jurídica obtida na faculdade de direito, da Universidade de Coimbra, em 1941. Ingressou na Faculdade de Letras da Universidade de Coimbra quase duas décadas depois, em 1958, e tornou-se seu professor catedrático em 1970. Centrou a sua investigação inicial em áreas como a religião, a política e a sociedade, vindo a destacar-se como historiador da cultura e da história das ideias, campo que procuraria fixar. Oriundo do direito, a sua formação teórica, epistemológica e metodológica ter-se-á realizado, quiçá mais visível do que noutros, no exercício da pesquisa. Inicialmente a sua produção científica surge marcada por preocupações com a heurística tendo evoluído no sentido de uma crescente atenção dispensada à teoria e à filosofia da história acompanhada de um recurso à interdisciplinaridade, na produção de uma história que concebia totalizante. Iniciando a atividade docente com a recém-criada, em 1957, História da Cultura Portuguesa, coube-lhe ainda reger História da Filosofia em Portugal e História da Cultura Moderna. A partir de 1961 passou a dirigir o curso de seminário de cultura portuguesa. Compaginando investigação e magistério, revelou, ainda, "capacidade organizativa e dinâmica de ação como gestor, no âmbito da pesquisa histórica» como o seu percurso académico e profissional bem ilustra, a par com o facto de «ter criado escola» 133 .

Apesar do destaque deste contributo inovador a apreciação e avaliação que estoutro professor da Universidade de Lisboa, Oliveira Marques, fez da reforma de 1957, não foi propriamente positiva. Considerava-a desfasada do seu tempo e atribuía-lhe um caráter «marcadamente clerical e reacionário»134, concedia-lhe, contudo, algumas vantagens e destacava o facto de ter separado a História da Filosofia. Neste seu texto, a que já nos tínhamos referido anteriormente, Oliveira Marques reporta-se ao período em que foi docente

133 Mendes, J. M. Amado - A renovação da historiografia portuguesa. In Torgal, Luís Reis; Mendes, José Maria Amado; Catroga, Fernando - ob. cit., pp. 297-299 e 304-311.

134 Marques, A. H. de Oliveira - ob. cit., 1991, p. 437. 
da Faculdade de Letras da Universidade de Lisboa, entre novembro de 1957 e 1964, onde, para além de descrever o seu serviço docente, reflete sobre a carreira universitária e avalia o peso da obtenção do grau de doutor no percurso académico e no serviço docente nestes termos:

Mas, para além de regências, presidências de júris e orientações de teses, o doutoramento pouca autonomia nos concedia. Os doutores mantinham a denominação de "assistentes" - Primeiros Assistentes - e todo o poder e capacidade de decisão continuavam nas mãos dos catedráticos. Eram eles que administravam a Faculdade, que compunham o Conselho Escolar e que elegiam um dos seus membros para Secretário. O Director era, evidentemente, um deles, mas de nomeação governamental. Eram eles ainda quem distribuía o serviço docente, ao sabor de conveniências e caprichos, muitas vezes sobrepostos ao saber científico real. Quando os catedráticos eram especialmente autoritários e ciosos, até ao exagero, das suas prerrogativas, os doutorados podiam sofrer vexames e humilhações superiores até à dos Segundos Assistentes. Só com a situação de Professor Extraordinário, o que requeria nova tese e novas provas públicas, se ingressava no quadro e se conseguia, enfim, uma relativa independência ${ }^{135}$.

Para concluir esta nossa abordagem dos modelos de formação em história, mais do que aferir, eventualmente até pelo cruzamento de fontes, o conteúdo da apreciação de Oliveira Marques, não podemos negar que este é um outro aspeto que não pode ser arredado de uma reflexão sobre as instituições de produção, reprodução e divulgação de discursos historiográfico, tanto mais que ele se interliga, nomeadamente com a ação que referenciámos em Jorge Borges de Macedo e Sebastião Silva Dias. O testemunho vem reforçar o que Adérito Sedas Nunes sublinhava há mais de quatro décadas, quando discutia problemas epistemológicos e de pragmática das ciências sociais e referenciava, necessariamente para efeitos analíticos, a necessidade de se considerar a ciência como corpo de conhecimentos e resultados bem como sistema de

135 Idem, ibidem, p. 438. 
produção ${ }^{136}$. Na verdade, é importante termos presente que o conhecimento das instituições de produção, reprodução e divulgação da história passava pela compreensão de que o corpo de conhecimentos e resultados da história, dependia (e depende), do seu sistema de produção, isto é, de quem eram (ou são) os historiadores, dos meios de produção que mobilizavam (ou mobilizam) (métodos, conceitos e teorias disponíveis, instrumentos materiais, técnicas de pesquisa, recursos, etc.) e do que eram (e são) as faculdades de letras, enquanto estruturas e instituições sociais, por relação à opinião expressa por Oliveira Marques, sendo importante conhecer a sua estrutura interna de poderes e quais os mecanismos da sua gestão administrativa e científica.

\section{Conclusão}

Como breves notas finais destaquemos algumas linhas de força que ao longo da narrativa fomos desfiando. Desde logo uma invariante, os modelos de ensino e de aprendizagem da história estiveram sempre associados à procura e oferta educativa de professores no ensino secundário ou liceal, a par com a preocupação da formação cultural e científica de outros quadros para a formação social portuguesa. Desde as alterações introduzidas por Jaime Moniz no Curso Superior de Letras, em 1901, ao diploma de Leite Pinto (1957) que, como vimos, sublinha a necessidade de melhoria da formação dos professores do ensino secundário, em geral, e do liceal em particular. Constitui outra invariante, a tendência irreversível, pelo menos no âmbito da política educativa do período estudado, para a especialização, com o consequente aprofundamento do estudo da história, em termos disciplinares e com o alargamento dos períodos mas também das temáticas.

Nas faculdades de letras durante o meio século que analisámos, existiram duas realidades organizacionais distintas. Uma, pensada na lógica do self-government compaginando liberdade e responsabilidade, visível na autonomia dos estudantes para a arrumação das disciplinas, na ausência de precedências,

136 Cf. Nunes, A. Sedas - Questões preliminares sobre as ciências sociais. In Análise Social. Volume VIII. N. $30-31.1970$, pp. 211-215. 
no caráter facultativo das lições magistrais, na obrigatoriedade de participação nos trabalhos práticos e nos exercícios de investigação, constituindo uma oferta educativa que pretendia conferir uma formação cultural e científica para a intervenção e modernização da sociedade. Estoutra, espaldada no controlo e na conformação ideológica dos estudantes, e professores, pressente-se na fixação do plano de estudos, na introdução das precedências, na obrigatoriedade das aulas, nos conteúdos lecionados mas, provavelmente, também na ambiência e no relacionamento entre alunos, entre os docentes e nas relações entre ambos. As vivências que assinalámos para a Faculdade de Letras de Lisboa parece ser exemplo do que afirmamos. A alteração do mandato para educação produziu uma evolução neste segundo modelo organizacional, focalizado não tanto no plano ideológico mas mais na preparação técnica e científica como resposta às necessidades do mercado de trabalho e à introdução da planificação em educação, muito visível na alteração do processo de avaliação, emergindo a preocupação com a certificação da formação adquirida em face do aumento significativo do número de alunos a frequentar a faculdade de letras, em geral e, em particular, as licenciaturas em ciências históricas e filosóficas e em história. Invariante no plano organizacional foi a autonomia em certos domínios, aparentemente sem restrições, de cada docente. Conteúdos, e necessariamente sobre os objetivos das cadeiras, repousavam sobre o arbítrio individual de cada docente. A questão não deixou de nos interpelar na justa medida em que essa autonomia se articulava, ou não, com a unidade e a lógica organizadora do plano de estudos, tanto mais que, dependendo do grau, se poderia tornar contraditória com a existência de precedencias.

A presença exuberante das ciências auxiliares da história que, se não deixa de traduzir uma preocupação de natureza metodológica no sentido de dotar os estudantes de um aparato crítico, a manutenção do seu peso significativo denúncia as opções do historicismo neo-metódico e incrementou o estudo dos períodos desde a pré-história à época medieval. Simultaneamente, como se compreende, contribuiu para marginalizar o estudo da história contemporânea, em consonância com a desconfiança intrínseca do Estado Novo, por razões ideológicas e políticas. Ainda assim, como assinalámos, a historiografia portuguesa não deixou de se afirmar por paradigmas contra-hegemónicos, como foram os casos por nós elencados, de Virgínia Rau, Jorge Borges de 
Macedo e José Sebastião da Silva Dias. Neste âmbito específico, embora também noutros, a orientação permitir-nos-ia aceder ao conhecimento de procedimentos e conteúdos, constituindo uma desocultação reveladora de dimensões importantes no domínio da produção, reprodução e divulgação da história.

Por último, as dimensões da educação informal e não formal. Na verdade, as vivências e os espaços de socialização criados, não na faculdade mas muitas vezes a partir da faculdade, ainda que por razões e processos muito diversos, parecem ter-se revelado importantes para a aprendizagem e formação dos nossos historiadores. A análise biográfica e prosopográfica é, como bem sabemos, uma importante dimensão do estudo da aprendizagem da história como, uma vez mais, fica comprovado.

\section{Referências bibliográficas}

\section{Legislação}

Decreto de 19 de agosto de 1911. Colecção oficial de legislação portuguesa. Volume II. Lisboa, pp. 1617-1634.

Decreto de 9 de maio de 1911. Colecção oficial de legislação portuguesa. Volume I. Lisboa, pp. 816-820.

Decreto n. ${ }^{\circ} 12462$, de 2 de outubro. Diário de Governo. I Série. ‥ ${ }^{\circ} 220$, de 2 de outubro de 1926 Decreto n. ${ }^{\circ}$ 12677, de 12 de novembro. Diário de Governo. I Série. ‥ ${ }^{\circ} 220$, de 17 de novembro de 1926. Decreto n. ${ }^{\circ}$ 16623, de 18 de março. Diário de Governo. I Série. N. ${ }^{\circ}$ 62, de 18 de março de 1929. Decreto n. ${ }^{\circ} 17063$, de 3 de julho. Diário de Governo. I Série. N. ${ }^{\circ} 149$, de 3 de julho de 1929. Decreto n. ${ }^{\circ}$ 17305, de 5 de setembro. Diário de Governo. I Série. N. ${ }^{\circ} 204$, de 5 de setembro de 1929. Decreto n. ${ }^{\circ}$ 18:003, de 25 de fevereiro. Diário de Governo. I Série. N. ${ }^{\circ} 46$, de 25 de fevereiro de 1930. Decreto n. ${ }^{\circ}$ 4:651, de 14 de julho. Diário de Governo. I ${ }^{a}$ Série. N. ${ }^{\circ}$ 157, de 14 de julho de 1918. Decreto n. ${ }^{\circ}$ 4:945, de 1 de novembro. Diário de Governo. I Série. ‥ ${ }^{\circ}$ 241, 7 de novembro de 1918. Decreto n. ${ }^{\circ} 41341$, de 30 de outubro. In Diário do Governo. I Série. N. ${ }^{\circ} 246$, de 30 de outubro de 1957.

Decreto n. ${ }^{\circ}$ 47609, de 27 de março. Diário de Governo. I Série. N. ${ }^{\circ}$ 73, de 27 de março de 1967. Decreto n. ${ }^{\circ}$ 48627, de 12 de outubro. Diário de Governo. I Série. N. ${ }^{\circ}$ 241, de 12 de outubro de 1968. Decreto n. ${ }^{\circ}$, de 24 de dezembro. In Diário de Governo. N. ${ }^{\circ}$ 224, de 28 de dezembro de 1901. Decreto n. ${ }^{\circ}$ 5:770, de 10 de maio. Diário de Governo. I $^{\text {a Série. N. }}{ }^{\circ}$ 98, 10 de maio de 1919 Lei n. ${ }^{\circ} 639$ de 20 de novembro de 1916. Diário de Governo. I $^{a}$ Série. N. ${ }^{\circ} 234$, de 20 de novembro. Portaria n. ${ }^{\circ}$ 18785, de 23 de outubro. Diário de Governo. I Série. N. ${ }^{\circ} 246$, de 23 de outubro de 1961. 


\section{Fontes impressas e bibliografia}

A Faculdade de Letras da Universidade de Coimbra ao País. Coimbra: Tipografia França Amado, 1919.

Aguilar, Manuel Busquets - O Curso Superior de Letras (1858-1911). Lisboa, 1939

Bourdé, G; Martin, H. - As escolas históricas. Lisboa: Publicações Europa-América, 2012.

Braga, Teófilo - Historia da Universidade de Coimbra nas suas relações com a instrucção publica portugueza. Tomo IV. Lisboa: Por ordem e na Typographia da Academia Real das Sciencias, 1902.

Catroga, F. - Luís Ferrand de Almeida e António de Oliveira no ensino de Teoria da História. In Revista Portuguesa de História. Tomo 36. Volume II, 2002-2004, pp. 125-134.

Coelho, F. Adolfo - Le Cours Supérieur de Lettres - mémoire. Paris/Lisbonne: Aillaud \& Cie, 1900.

Coelho, F. Adolfo - O Curso Superior de Letras e os cursos de habilitação para o magistério secundário. In Notas sobre Portugal. Volume I. Lisboa: Imprensa Nacional, 1908, pp. 437-447.

Colecção de leis, regulamentos, portarias e ordens relativas ao Curso Superior de letras. Lisboa: Imprensa Nacional, 1883.

Correia, Margarita - Homonímia e polissemia - contributos para a delimitação dos conceitos. In Palavras, n. ${ }^{\circ}$ 19, Lisboa: Associação dos Professores de Português. Disponível em U. R. L.: http:// www.iltec.pt/pdf/wpapers/2000-mcorreia-homonimia_polissemia.pdf [Consultada a 13-9-2011].

Couvaneiro, João L. S. F. - O Curso Superior de Letras (1861-1911). Nos primórdios das Ciências Humanas em Portugal. Lisboa: Universidade/Faculdade de Letras/Departamento de História, 2012. Dissertação de doutoramento em História (Especialidade: História Contemporânea). Disponível em U. R. L.: http://repositorio.ul.pt/handle/10451/7500 [Consultada a 13-2--2013].

Dores, H. G. - A História da Faculdade de Letras de Lisboa (1911-1930). Lisboa: Universidade/ Faculdade de Letras/Departamento de História, 2008. Dissertação de mestrado. Disponível em U. R. L.: http://repositorio.ul.pt/handle/10451/424 [Consultado em 13-2-2013]

Durkheim, É. - Educação e Sociologia. Lisboa: Edições 70 Lda., 2009

Ferreira, A. G.; Mota, L. - Memória(s) 30 anos depois. (Entre)vistas a pretexto da formação de professores no PREC. In Estudos do Século XX. N. ${ }^{\circ} 11,2011$, pp. 69-85.

Ferreira, A. G.; Mota, L. - Memories of life experiences in a teacher training institution during the revolution. In Paedagogica Historica: International Journal of the History of Education. DOI: 10.1080/00309230.2012.750375. 2013, pp. 1-18 (link http://dx.doi.org/10.1080/00309230.2012.7 50375)

Ferry, G. - Le trajet de la formation: les enseignants entre la théorie et la pratique. Paris: Dunod, 1983. França, J.-A. - Memórias para o ano 2000. Lisboa: Livros Horizonte, 2001.

Garcia, Manuel Emídio - Importância dos estudos históricos nas ciências jurídico-sociais e o ensino da história em Portugal. In O Instituto, volume XIX, n. ${ }^{\circ} 4,1874$, pp. 151-153.

Godinho, V. M. - Saudade de lutar pelo futuro. Fernando Piteira Santos. In Godinho, V. M. Ensaios e estudos - compreender o mundo de hoje. Volume II. Lisboa: Sá da Costa: 2010, p. 503-515.

Godinho, Vitorino Magalhães - Ensaios III. Sobre Teoria da História e Historiografia. Lisboa: Livraria Sá da Costa Editora, 1971

Gomes, Joaquim Ferreira - Novos Estudos de História e de Pedagogia. Coimbra: Livraria Almedina, 1986, pp. 67-96. 
Homem, A. L. Carvalho - A história que nos fez e a História que se faz: da primeira à segunda fase da Faculdade de Letras do Porto. In Revista de História do Centro de História da Universidade. Volume XI. Porto, 1991, pp. 227-240

Homem, A. L. Carvalho - A Idade Média nas universidades portuguesas (1911-1987). Legislação, ensino, investigação. Revista da Faculdade de Letras. II Série. Volume IV, Porto, 1993, pp. $351-361$

Homem, A. L. Carvalho - Os 25 anos da Faculdade de Letras: passado e presente. In Revista da Faculdade de Letras. II Série. Volume IV, Porto, 1987, pp. 293-307

Homem, A. L. Carvalho - Os historiadores, esses desconhecidos. In Revista Portuguesa de História. Tomo XXIX, 1994, pp. 33-53

Homem, A. L. Carvalho - Revistas universitárias de História no Portugal do século XX. In Revista de História das Ideias. História, Memória, Nação. Volume 18. 1996, pp. 339-372.

Homem, A. L. Carvalho - Saber positivo e teorização nos primitivos currículos da licenciatura em história (1957 e 1968). História, Revista da Faculdade de Letras da Universidade. IV Série. Volume 1. Porto, 2011, pp. 23-27.

Houaiss, Antônio; Villar, Mauro de Salles - Dicionário Houaiss da Língua Portuguesa. Tomo IV FRE-MER. Lisboa: Círculo de Leitores, 2003, pp. 2109-2110. ISBN 972-42-2809-6

Macedo, J. Borges de - A situação económica no tempo de Pombal. Alguns aspetos. Lisboa: Moraes Editores, 1982 [1951].

Macedo, J. Borges de - Itinerário de uma vida pública, cultural e científica. Lisboa: Edições Colibri, 1991.

Machado, F. F. - História de Portugal. Súmula das lições magistrais de História de Portugal $\left(1^{\circ}\right.$ Ano) pelo Exmo. Professor Doutor Senhor Doutor Manuel Gonçalves Cerejeira, no ano lectivo de 1927-1928, na Faculdade de Letras da Universidade de Coimbra. Coimbra: Tipografia da Gráfica Conimbricense, 1928.

Magalhães, Joaquim Romero de - Oração de Sapiência proferida na abertura solene do ano letivo: 16 de Setembro de 2009. Coimbra: FEUC, 2009.

Marques, A. H. de Oliveira - A Universidade do Estado Novo. Memórias de um percurso universitário. In Universidade(s). História. Memória. Perspetivas. Actas do Congresso "História da Universidade" (No $7^{\circ}$ Centenário da sua Fundação). Volume 5. Coimbra: Comissão Organizadora do Congresso, 1991, pp. 431-442.

Marques, A. H. de Oliveira - Ensaios de Historiografia Portuguesa. Lisboa: Palas Editoras, Lda., 1988

Matos, S. C. - História, mitologia e imaginário nacional. A história no curso dos liceus (18951939). Lisboa: Livros Horizonte, 1990.

Matos, Sérgio Campos - O Curso Superior de Letras e a Vulgarização Histórica em Portugal: Projetos em Confronto (1858-1901). In Universidade(s). História. Memória. Perspetivas. Atas 1. Congresso História da Universidade. Coimbra: Comissão Organizadora do Congresso "História da Universidade", 1991, pp. 371-373.

Matos, Sérgio Campos - O Curso Superior de Letras e a Vulgarização Histórica em Portugal: Projetos em Confronto (1858-1901). In Universidade(s). História. Memória. Perspetivas. Actas do Congresso "História da Universidade" (No $7^{\circ}$ Centenário da sua Fundação). Volume 1. Coimbra: Comissão Organizadora do Congresso, 1991, pp. 367-388. 
Mendes, J. Amado - A História da Faculdade de Letras da Universidade de Coimbra: Investigação e Ensino (1911-1926). In Universidade(s). História. Memória. Perspetivas. Actas do Congresso "História da Universidade" (No $7^{\circ}$ Centenário da sua Fundação). Volume 1. Coimbra: Comissão Organizadora do Congresso, 1991, pp. 477-498.

Mendes, J. Amado - Desenvolvimento e estruturação da historiografia portuguesa. In Torgal, Luís Reis; Mendes, José Maria Amado; Catroga, Fernando - História da História em Portugal. Séculos XIX e XX. Lisboa: Círculo de Leitores, 1996, pp. 161-217.

Mendes, J. M. Amado - A renovação da historiografia portuguesa. In Torgal, Luís Reis; Mendes, José Maria Amado; Catroga, Fernando - História da História em Portugal. Séculos XIX e XX. Lisboa: Círculo de Leitores, 1996, pp. 277-344

Mónica, Maria Filomena - D. Pedro V. Casais de Mem Martins/Rio de Mouro: Círculo de Leitores e Centro de Estudos dos Povos e Culturas de Expressão Portuguesa/Temas e Debates, 2007.

Mota, L. - A Escola do Magistério Primário de Coimbra (1942-1989). Entre Ideologia, Memória e História. Tomo I. Coimbra: Faculdade de Letras da Universidade, 2006. Dissertação de doutoramento.

Mota, Luís - A reforma da Universidade enquanto projeto pedagógico (e social) de formação de elites. Separata da Revista de História das Ideias. Volume 22. Coimbra: Faculdade de Letras, 2001. Nunes, A. Sedas - Questões preliminares sobre as ciências sociais. In Análise Social. Volume VIII. N. ${ }^{\circ}$ 30-31. 1970, pp. 211-215.

Nunes, João Paulo Avelãs - A História Económica e Social na Faculdade de Letras da Universidade de Coimbra: o historicismo neo-metódico: ascensão e queda de um paradigma historiográfico: 1911-1974. Lisboa: Instituto de Inovação Educacional, 1995.

Nunes, L. R. M. - Zófimo Consiglieri Pedroso. Vida, obra e ação política. Lisboa: Faculdade de Ciências Sociais e Humanas/Universidade Nova de Lisboa, 1993. Dissertação de mestrado.

Oliveira, António de - As Histórias da Minha Geração. Uma Perspetiva Historiográfica. In Estudos em Homenagem a Luís António de Oliveira Ramos. Porto: Faculdade de Letras da Universidade do Porto, 2004, pp. 83-98.

Pegado, Guilherme José António Dias - Projecto de lei da organisação gerál da universidade de Portugal, dedicádo a Nação portuguesa [...].Coimbra: Na Imprensa da Universidade, 1835.

Rau, Virgínia - Estudos sobre bistória económica e social do Antigo Regime. Introdução e organização de José Manuel Garcia. Lisboa: Editorial Presença, 1984.

Ribeiro, O. - Opúsculos. Volume II. Lisboa: Fundação Calouste Gulbenkian, 1989, pp. 141-161.

Sá, Victor de - Notas Sobre o Ensino da História na $1^{\mathrm{a}}$ Faculdade de Letras do Porto. In Revista da Faculdade de Letras do Porto. História. Disponível em U. R. L. http://ler.letras.up.pt/uploads/ ficheiros/2046.pdf [Consultada a 2-8-2011]

Saraiva, J. H. - Álbum de memórias. $3^{a}$ e $4^{a}$ décadas (anos 40 e 40). A década da esperança e o tempo das campanhas. [s.1.]: Edições «Sol», 2007.

Sérgio, A. - Educação Cívica. Lisboa: Livraria Sá da Costa, 1984 [1914].

Serrão, J. - Os anos 40. Condicionalismos gerais. Um testemunho. Uma aproximação. In Os anos 40 na Arte Portuguesa. A cultura nos anos 40. Colóquios. Volume VI. Lisboa: Fundação Calouste Gulbenkian, 1982, pp. 13-31.

Soares, M. - Portugal amordaçado. Depoimento sobre os anos do fascismo. Lisboa: Arcádia, 1974. 
Sousa, J. M. Guedes de - Vitorino Magalhães Godinho: história e cidadania nos anos 40. Lisboa: Faculdade de Letras da Universidade, 2012. Dissertação de mestrado em História (História Moderna e Contemporânea). Disponível em U. R. L.: http://repositorio.ul.pt/bitstream/10451/6905/1/ ulfl122521_tm.pdf [Consultado a 19-2.2013].

Tavares, L. F. R. - Curso Superior de Letras: Inventário. Lisboa: Universidade/Faculdade de Letras/ Departamento de Ciências da Documentação e Informação. 2009. Relatório de Estágio/Mestrado. Disponível em U. R. L.: http://repositorio.ul.pt/bitstream/10451/432/1/21367_ulfl071255_tm.pdf [Consultado em 13-2-2013]

Torgal, Luís Reis - Ensino da História. In Torgal, Luís Reis; Mendes, José Maria Amado; Catroga, Fernando - História da História em Portugal. Séculos XIX e XX. Lisboa: Círculo de Leitores, 1996, pp. 431-489.

Torgal, Luís Reis; Mendes, José Maria Amado; Catroga, Fernando - História da História em Portugal. Séculos XIX e XX. Lisboa: Círculo de Leitores, 1996.

Torgal, Luís Reis; Vargues, Isabel Nobre - A revolução de 1820 e a instrução pública. Porto: Paisagem Editora, 1984. 